\title{
قراءة نقدية في مصطلح النص في الفكر الأصولي
}

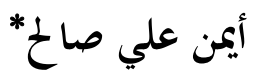

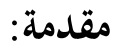

يتمثل التداخل الاصطلاحي - كما يلاحظه المتخصصون في علم أصول الفقه- في أمرين: أحدهما: كثرة الترادف، أي: وجود أكثر من لفظ اصطلاحي للمدلول الواحد، كما هو الحال، مثلاً، في "مفهوم الموافقة"، الذي سِّمي بتسميات عدة ك "دلالة النص"، و "فحوى الخطاب"، و"لحن الخطاب"، و "تنبيه الخطاب"، و"القياس الجلي"، وغير ذلك. والأمر الآخر: وهو الأخطر، كثرة الاشتراك، أي: وجود أكثر من مدلول للفظ الاصطلاحي الواحد، كما هو الحال، مثلاً، في "العلة" التي تُطلق كما يقول الغزالي، رحمه الله تعالى: "على العلامة الضابطة لمحل الحكم، وقد تطلق على الباعث الداعي إلى الحكم، وهو وجه المصلحة، وقد تطلق على السبب الموجب للحكم."1 ولقد كان لمذا التداخل الاصطلاحي أثثر كبيرٌ في بروز ظاهرة أخرى هي ظاهرة "الخلاف اللفظي" في كثير من المباحث الأصولية، حيث يثور الجدل ويحتدم النزاع لا على شيء وإنما لأن واحداً من الفريقين المتنازعين أطلق لفظاً وأراد به شيئاً ففهم الفريق الآخر منه معنى آخر. ولقد نبَّه الغزالي قديماً إلى هذه الظاهرة بالقول: "معظم الأغاليط والاشتباهات ثارت من الشغف بإطلاق ألفاظ دون الوقوف على مداركها ومآخذها."2 وقال: "إنما منشأ الإشكال التخاوضُ في الأمور دون التوافق على حدودٍ معلومة لمقاصد العبارات فيُطلق المطلق عبارة على معنى يقصده، والخصم يفهم منه معنى آخر يستبد هو بالتعبير عنه، فيصير به النزاع ناشباً قائماً لا ينفصل أبد الدهر."3 وقال ابن حزم: "الأصل في كل بلاء بلاء وعماء وتخليط وفساد اختلاط أسماء، ووقوع اسم واحد على معاني كثيرة، فيخبر المخبر بذلك الاسم، وهو يريد أحد المعاني التي

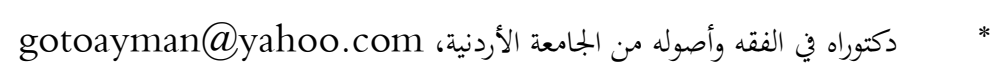

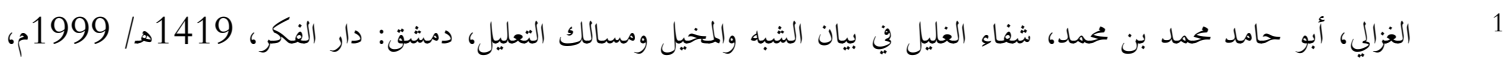

$$
\text { 2 }
$$


تحته فيحمله السامع على غير ذلك المعنى الذي أراد المخبر فيقع البلاء والإشكال. وهذا في الشريعة أضر شيء وأشده هلاكاً. "4

ومما يلقي شيئاً من الضوء على حجم ظاهرة الخلاف اللفظي في تراثنا الأصولي ما قاله د. عبد الكريم النملة في مقدمة المجلد الأول من كتابه الذي خصصه لتتبع هذه الظاهرة -قال: "وقد بلغ بجموع الخلافات التي درستها في هذا المجلد -فيما يخص المقدمات والحكم الشرعي- خمساً وخمسين خلافاً: منها تسعة وأربعون خلافاً بان، بعد التدبُّر والتدقيق، أن الخلاف لفظيٌّ لا ثمرة له. "5

ولن يستهجن الباحث بروز هاتين الظاهرتين: "الترادف الاصطلاحي" و"الخلاف اللفظي" في علم أصول الفقه التقليدي إذا ما أخذ في الحسبان الظروف التاريخية والعلمية التي تَشَّل في أجوائها هذا العلم. ومنها أن هذا العلم تشكل من بجموع علوم مختلفة، ولكل علم منها أربابه واصطلاحاته. وهذه العلوم هي الكلام والفقه واللغة. ومنها أن هذه العلوم، لا سيما الكلام والفقه، كانت ميادين للنزاع والجددال بين الفرق والمذاهب المختلفة. ولكل من هذه الفرق والمذاهب اصطلاحاتا الخاصة. فالمادة الكلامية كان الجدل فيها مستعراً بين المعتزلة والأشاعرة، والمادة الفقهية كان الخلاف فيها مستعراً بين الشافعية والحنفية. ومنها أيضاً أن

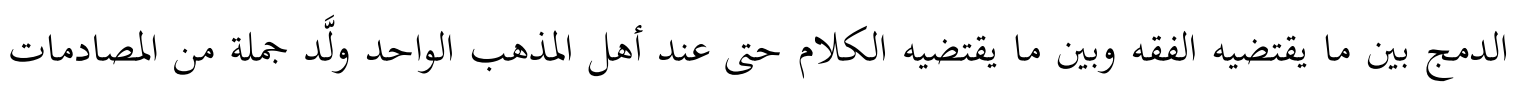
والتناقضات. خذ مثالاً على ذلك مسألة التعليل التي قبلها الأشاعرة في الممارسة الفقهية بينما رفضوها في الممارسة الكلامية، مما أدى إلى اضطراب مفهوم العلة عندهم. ومنها كذلك ضعف منهجية التوثيق في نقل الآراء والمذاهب عند كثير من الأصوليين، حيث كانوا يكتفون بالنقل عن بعضهم البعض وبما شاع بدلاً من العودة إلى المرجع الأصلي. وإن نظرة شاملة لكتاب "البرهان" لإمام الحرمين تطلعك على عدد جم من المسائل التي نبه الإمام على أنه إما أسيء نقلها عن المعتزلة أو أسيء فهمها عنهم. ونظرة أخرى إلى "البحر المحيط" تطلعك على أخطاء كثيرة في نقل المذاهب والآراء والاصطلاحات نبه الزركشي عليها؛ لأنه وضع بهي

$$
4
$$

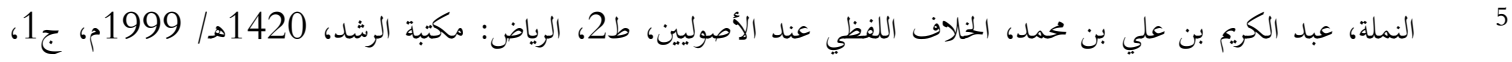
ص10 
لنفسه منهجية سليمة في نقل المذاهب بالعودة إلى كتب أصحاهما أنفسهم ما وسعه الجهد كما أشار إلى ذلك في مقدمة كتابه.

وهذه العوامل وغيرها، فضلاً عن تأثيرها المباشر في إيجاد ما أسميناه بـ "التداخل الاصطلاحي"، قد جعلت علم أصول الفقه يتخذ طابع الجدل والنقاش والاعتراض والرد والسؤال والجواب و وجعُل الحبَّة قُبَّة." وهذا قد أسهم بدوره أيضاً، بطريق غير مباشر، في انتشار واستشراء الظاهرة آنفة الذكر. ومن أهم ما يجب أن يضطلع به البحث الأصولي المعاصر، لا سيما بعد أن هدأت حدة الخلافات المذهبية الكلامية والفقهية في العصر الراهن، أن يعمد إلى هذا التراث الأصولي العظيم، والمليء بالجواهر والكنوز على الرغم من بعض مناحي القصور التي أصابته، فيخلصه من مشاكل الاصطلاح التي أتت على بعض جوانبه.

وبهذا نكون قد خطونا خطوة أولى في سبيل النهوض بعلم الأصول عن طريق فهم مصطلحاته وضبطها، لأن هذه المصطلحات تمثل: من جهة، اللَّنات التي بني بها هذا العلم قديماً، ومن جهة أخرى لئل اللبنات التي سيطور بها هذا البناء حديثاً. وعليه فالقضاء على "التداخل الاصطلاحي" سيمنحنا فائدتين لا غنى عنهما: سيمنحنا أولاً فهماً أعمق وأدق للمادة الأصولية القديمة، وسيمنحنا ثانياً وضوحاً وشفافية في سيكي بناء مادة أصولية جديدة. وفي هذا السياق يأتي هذا البحث بعنوان: "قراءة نقدية في مصطلح النص في الفكر الأصولي" ليضع حداً للتداخل الاصطلاحي الذي يكتنف مصطلح "النص" خاصة. هذا المصطلح الذي لم يجظ، وفي حدود علمنا، بقدر من البحوث والدراسات الأصولية تتناسب مع مستوى الجلدل الذي ثار حوله وحول ما أريد به، على الرغم من استعماله الكثيف على كل صعيد.

أولاً :النص في المعجم والاصطلاح وتطوره التاريخي

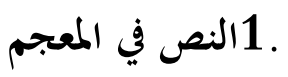

$$
6 \text { 6 الزركشي، محمد بن بمادر، البحر المحيط، قطر : وزارة الأوقاف والشؤون الإسلامية، ج1، 1413هـ/ 1992م، ص7 }
$$


يككنا أن نلخِّص ما قاله ابن منظور في كتابه الجامع "لسان العرب" حول المادة الثلاثية "ن ص ص" بالقول: إنّ الدلالة الأصلية لهذه المادة ومشتقاتحا تتركز في معنيين: أحدهما: الرفع والارتفاع، والآخر: منتهى الشيء ومبلغ غايته.

وفي سبيل رد باقي المعاني التي تفرعت عن الأصل "ن ص ص" إلى هذين المعنيين يمكنا القول:

$$
\text { أولاً: إن معنى الرفع والارتفاع هو المعنى الذي تطور: }
$$

1. إلى "الظهور" عن طريق علاقة التلازم بين الارتفاع والظهور فكلُّ مرفوٍ ظاهر، ولأجل الظهور هذا قيل: نص الكتاب والسنة، أي ما دل ظاهر لفظهما عليه. 2. وإلى "التعيين"، لأن كل شيء رفعته تكون قد أظهرته وعيّنته. 3. وإلى "حركة البعير إذا قام منتهضاً"، لأنه حيئذ يرفع رقبته وقوائمه. 4. وإلى "ما أقبل على الجبهة من الشعر"، لأنه في مكان رفيع. 5. وإلى "الاستواء والاستقامة"، لأغما يشتملان على رفع الظهر والعنق. 7. وإلى "تريك اللسان"، لأن تحريكه يتضمن رفعه أو رفع الصوت به. 7

8. وإلى "الإسناد إلى القائل"، لأن الإسناد رفع معنوي، ولذا سمَّى المحدِّثنون الحديث إذا عُزي إلى النبي، صلى الله عليه وسلم: حديثاً مرفوعاً. وثانياً: إن معنى منتهى الشيء ومبلغ غايته هو المعنى الذي تطور إلى "شدة السير"، لأنه منتهى سرعة الناقة، وإلى "شدة الأمر"، لأن المقصود هو منتهى الشدة، وإلى "السؤال المستقصي"، لأنه يستخرج منتهى الإجابة.

وقد يقال -وهذا تخمين يحتاج إلى تحقيق - بأن النصنصة بعمنى تحريك اللسان مصحفة عن النضنضة بالضاد المعجمة إذ إن لمما المعنى

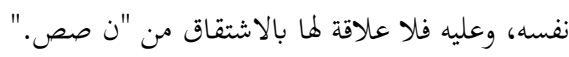


وبالاستناد إلى قانون تطور الألفاظ من الدلالة على الحسيات إلى الدلالة على المعنويات يمكننا القول

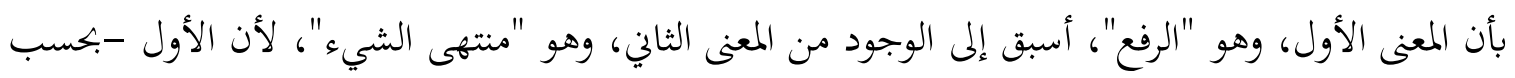
ما بسطه أهل اللغة من أمثلة- أكثر حسّية من الثاني. ولكن لا يبعد القول بأن هذين المعنيين ليسا منفصلين، بل هما جزآن لمعنى واحدٍ مركبٍ من كليهما، وهو "رفع الشيء إلى أقصى غايته." أي أن النص، في أصله اللغوي، لم يكن يعني رفعا مجرداً وإنما رفعاً مخصوصاً بكونه بلغ الغاية.

ويؤيد استنتاجَنا هذا، دلالةُ بعض المعاني التي تطور إليها اللفظ على لزوم توافر هذين المعنيين كليهما فيه: كالنَّص بمعنى الظاهر إلى الغاية، كما هو الحال في ظهور المِنَصَّة، ويف ظهور لفظ الكتاب والسنة -ولذا قال الباجي وابن السمعاني والعُكُبُري في تعريف "النص": هو "ما رُفع في بيانه إلى أقصى غاياته"-8 وكالنُصة بمعنى ما أقبل على الجبهة من الشعر، ولا يخفى كونُ الجبهة هي أرفع عضو في الإنسان. وكالنَّص بمعنى إسناد القول إلى الرئيس الأكبر، أي الرفع له إلى منتهى غايته وهي قائلُه الأول.

ولعل هذه العلاقة الوثيقة بين جزئي معنى النص (الرفع + الغاية) هي التي دفعت ابن فارس إلى الجمع بين هذين الجزأين في نسق واحد، وبالتالي إلى جعُلهما منبثقين عن أصل معنوي واحد لا أكثر، وذلك في معجمه الذي احتفل فيه بالدلالات الأصلية للكلمات. فقال في المادة "نص": "النون والصاد أصل صحيح

$$
\text { يدل على رفع وارتفاع وانتهاء في الشيء."9 . }
$$

ثمة قضية عامة تتعلق بمنهج البحث في تناول الاصطلاح:

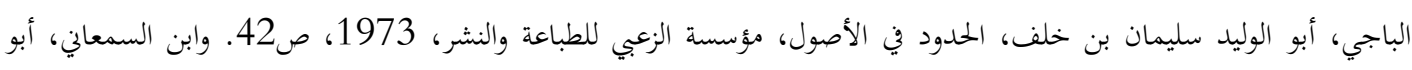

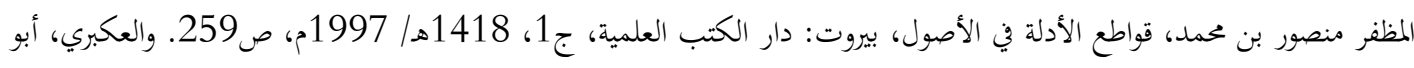

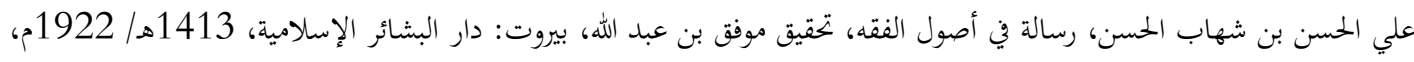
ص105 ابن فارس، أبو الحسن أحمد بن فارس بن زكريا، معجم مقاييس اللغة، تحقيق عبد السلام هارون، بيروت: دار الفكر، ج5، د.ت.، ص356، 357 
فحديث الباحثين حول مصطلح ما في علم من العلوم، أياً كان هذا العلم، يكون بطريقتين: الطريقة الأولى: "الطريقة التوصيفية": وأعني هما أن يصف الباحث المعنى الدقيق (= الجامع المانع) للمصطلح كما هو مستخدم في لغة أصحاب العلم. وقد يحدث أحياناً أن تتعدد المعاني المصطلح عليها للفظ الواحد في لغة أصحاب العلم، لأن هذا اللفظ مشترك عندهم بين عدة معاني. وعلى الباحث حيئذ أن يعدد هذه المعاني المستخدمة جميعا، ويصف كل واحد منها بدقة، ثم يبين المعنى الذي سيستخدمه هو في لغة بكثه. وفي هذه الطريقة قد يقع الباحث في خطأ التوصيف فيحدد معنى المصطلح بخلاف ما هو عليه في لغة أهل العلم، فلا يصح حيئذ الدفاع عن هذا الباحث بالقول: إنه لا مشاحّة في الاصطلاح، لأن هذا يُقال لمن يبتكر المصطلح أو يستخدمه لا لمن يصفه. قال القرافي معلِّقا على تعريف الفخر الرازي للاللفظ المرتحل" بأنه: "المنقول عن مسمّاه لغير علاقة": "ولم أر أحداً غيرَه قاله، فيكون باطلاًة؛ لأنه مُفَسِّرُ لاصطلاح الناس، فإذاذ لمُ يُوجد لغيره لم يكن اصطلاحاً لغيره."10 أما الطريقة الثانية هي: "الطريقة التعديلية": وأعني بها أن يُعدِّل أو يطوِر الباحثُ، كنتيجة لنطور العلم نفسه، من معنى المصطلح، كأن يزيد فيه قيداً أو ينقص منه أو يوسع في معناه أو يضيق منه أو ينقله لعلاقة ما إلى معنى قريب، وغير ذلك من أساليب تطوير دلالات الألفاظ. وهذا إنما يجوز بشرطين: أحدهما: وجود الحاجة الملحة للتعديل، لأن "تغيير الاصطلاح من غير فائدة في قوة الخطأ عند المحصلين" كما قال صاحب فواتح الرحوت. 11 والشرط الثاني: إفصاح الباحث عن نيته استخدامَ اللفظ بمعناه المطوَّر أو المعدَّل، والتذكير بذلك كلما اقتضت الضرورة، وذلك حتى لا يقع قارئ البحث في الالتباس وسوء الفهم.

وأما القضية الخاصة بمنهج البحث في تناول الاصطلاح فهي نسبية القطعية والظنية في الخطاب الشرعي. وأعني هما، بإيماز، أن الخطاب الشرعي الواحد، سواء أكان من الكتاب أو السنة، لا بد له، مهما كانت درجة الوضوح أو الغموض التي يتسم بها، من أن يشتمل على نوعي الدلالة: القطعي والظني في الآن نفسه. أي أنه لا يوجد -أو يكاد لا يوجد- خطاب شرعي "قطعي الدلالة" مطلقاً، أو "ظني الدلالة"

القرافي، شهاب الدين أمد بن إدريس، شرح تنقيح الفصول في اختصار الخصول في الأصول، بيروت: دار الفكر، 1418هـ

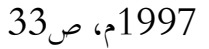
الأنصاري، عبد العلي محمد بن نظام الدين، فواتح الرموت بشرح مسلم الثبوت، بيروت: دار الكتب العلمية، ط2، ج1، ص407 
مطلقاً، بل هو "قطعي الدلالة" بالنسبة لمعنى أو معاني معينة، و"ظني الدلالة" بالنسبة لمعنى أو معالٍٍ أُخرَ. قال الغزالي، رحمه الله تعالى: "يجوز أن يكون اللفظ الواحدُ: نصاً (= قاطعاً)، ظاهراً (= ظنياً)، مجملاً (=

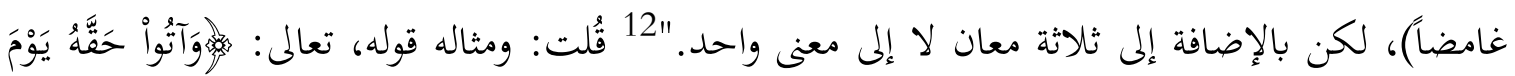

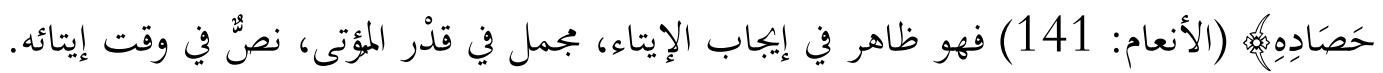

\section{3.}

نلاحظ أن معنى اللفظ "نص" قد تطور -والعلم عند الله تعالى- من معنى "الففع والارتفاع" إلى معنى "الظهور" وذلك لعلاقة التلازم بين الارتفاع والظهور.

أ. ومن هنا نشأ الاصطلاح العلمي الأول لـ "النص" وهو اللفظ أو الخطاب واضح الدلالة أو الظاهر، سواء أكان قطعياً أو ظنياً. ويدل على هذا استخدامُ النص بهذا المعنى في لغة الإمام الشافعي (ت 204هـ) نفسه مؤسس علم الأصول. فالشافعي يقابل في لغته بين النص والدلالة، وبين النص والجملة، وبين النص والاستنباط، وبين النص والقياس، وأحياناً بين النص والسنة، 13 ويندر في لغته استخدام لفظ النص مجرداً، بل الغالب عليه استخدام النص مضافاً فيقول: نص الكتاب، ونص التنزيل، ونص الخبر، ونص السنة.

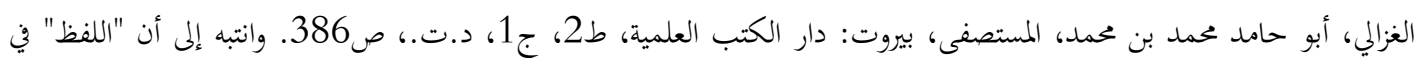

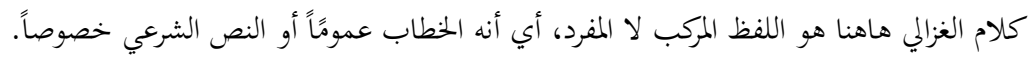

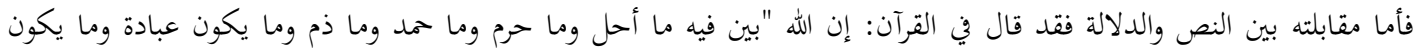

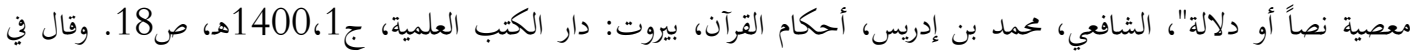

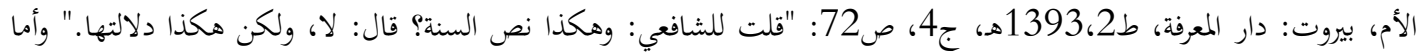

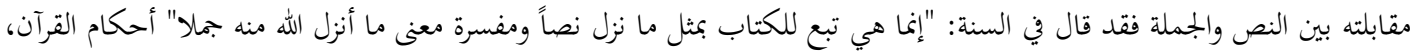

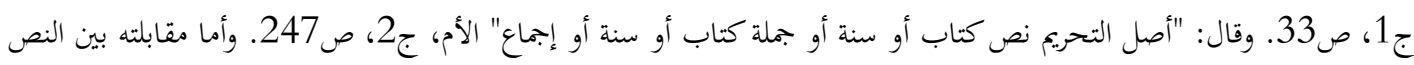

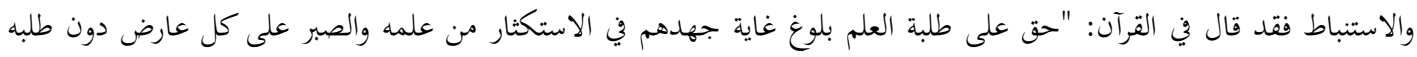

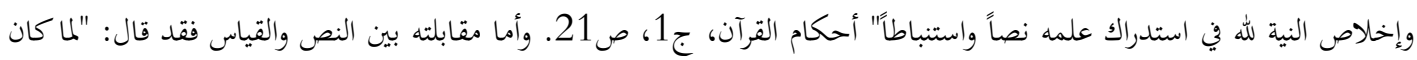

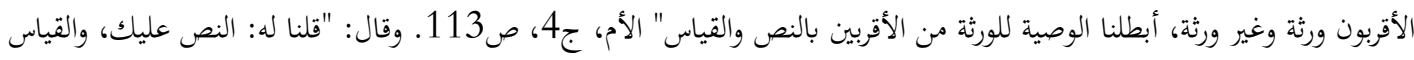

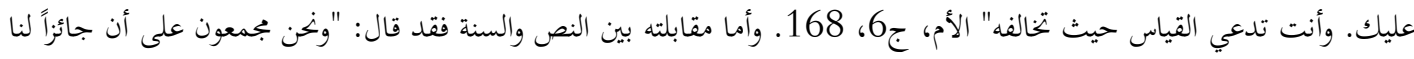

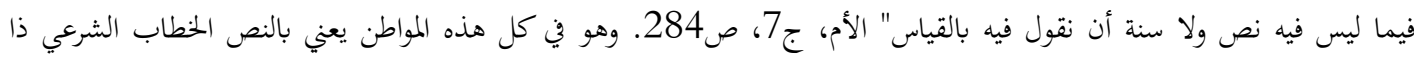


ولعل هذا الاصطلاح هو الذي ظل شائعا في لغة المتقدمين من أصوليين وفقهاء، فمثلاً استخدَمَ الإمام أحمد (ت 241هـ) النص بهذا الاصطلاح. 14 والكرخي (ت 340هـ) من الحنفية عرّف النص بما عرفه به الإمام الشافعي، 15 وكذلك فعل الجصاص (ت 370هـ).

ب. وبعد ذلك ولربما في النصف الأخير من القرن الرابع الهجري نشأ إلى جوار استخدام النص بمعنى الواضح استخدامُ آخرُ خاصٌ بنوع واحد من الوضوح: هو الوضوح الذي بلغ الغاية التي لا مزيد عليها وهي القطع. ومن هنا نشأ استخدام النص بمعنى اللفظ غير القابل للاحتمال كأسماء الأعداد وأسماء الأعيان. وإنما قلنا: إن هذا الاصطلاح كان قد نشأ في النصف الأخير القرن الرابع الهجري لأنا وجدنا الجصاص (ت 370هـ) عند كلامه حول النص 16 يدافع -من جهة- عن صدق اسم النص على كل الألفاظ الواضحة حتى المختملة منها كاللفظ العام، ويطعن -من جهة أخرى- في قطعية أسماء الأعداد والأعيان. وهذا يدل على أن النص بمعنى "القاطع" كان مصطلحاً شائعاً في عصر الجصاص، وإلا لما احتاج إلى مثل هذا الدفاع عن الاصطلاح القديم. وقد وجدنا بالفعل أن أبا حامد المروروذي من المتقدمين (ت 362هـ) 17 يُعرف النص بأنه: "ما عَري لفظه عن الشِّرَكة وخلص معناه من الشبهة. "18 وكذلك وجدنانا أبا علي الطبري (ت 400هـ) يقول بـ "عزة النصوص."19 ثم لا تسل عن فشو هذا الاصطلاح بعد هذه الفترة على يد الباقلاني (ت 403ه) ومَن بعَده.

14 نقله عنه، أبو البركات ابن تيمية، المسودة، ص574. وانظر كلامه عند حديثا حول اصطلاح النص بمعنى الواضح.

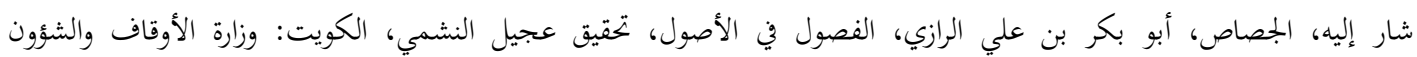

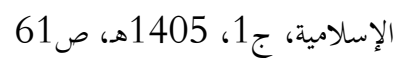
16

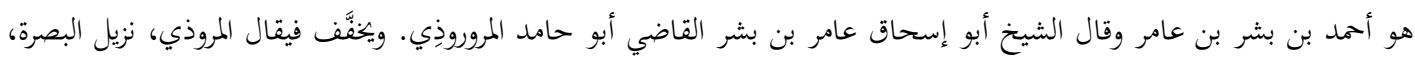

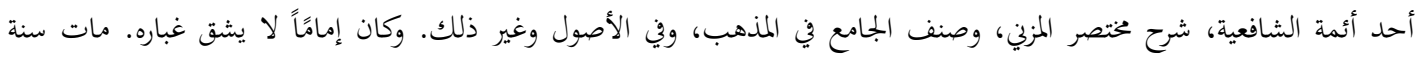

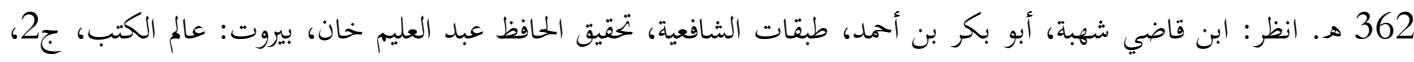

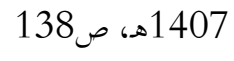

$$
\text { المقله عنه، الزركشي، محمد بن بهادر، البحر الخيط، مرجع سابق، ص463 ص464 }
$$


ج. أما الاصطلاح الثالث للنص وهو كون النص بمعنى الخطاب الشرعي من كتاب أو سنة بغض النظر عن دلالته، فقد رأى د. نصر أبو زيد أنه اصطلاح حديث ومعاصر لم يكن يعرفه الأسلاف. قال: "وإذا كنّا لا نجزم يقينا بكيفية التحول الدلالي الذي حدث للدال "نص" فلعل فيما يذكره ابن خلدون (ت 808هـ) عن المشتغلين بالفلسفة أغم كانوا يطلقون على كتاب المنطق لأرسطو اسم "النص" ما يساعدنا قليلاً على استشفاف جذور التحول"، 20 وقال: في دلالة النص على معنى اللفظ الواضح: "ظلّت تلك الدلالة الاصطلاحية هي السائدة في الخطاب العربي حتى القرن السابع الهجري."21 ورأيه هذا خالٍ من الدقة التاريخية على الإطلاق. 22 فالذي نقطع به تاريخيا أن الأصوليين قد استخدموا النص بهذا المعنى منذ أواسط القرن الخامس الهجري على الأقل، بل إن بعضهم قد عرف به كابن حزم (ت 456هـ) حينما قال: "النص هو اللفظ الوارد في القرآن أو السنة المستدَّل به على حكم الأشياء،"23 وكالغزالي (ت 505هـ) حينما قال: "وأشرنا بالنص إلى الكتاب والسنة."24 أما بعد القرن السادس الهجري فلا تسل عن فشوّ النص بهذا الإطلاق على ألسنة الأصوليين لا سيما عند الاستدلال على المسائل. وأدنى نظرة في كتاب الرازي أو الآمدي تكشف عن ذلك. أما استعمال النص بهذا الإطلاق في المراحل المبكرة من التدوين الأصولي فلا نستطيع الجزم به. لكن ثمة بوادر قد تدل على وجوده:

منها: ما أورده ابن منظور في سِياق كلام ابن الأعرابي 25 عالم اللغة المعروف (ت 231هـ) من أن النص يرد بمعنى "التوقيف."26 والتوقيف -في لغة القدماء- هو الكتاب والسنة، كما يدل عليه كلام الإمام

$$
21 \text { 20 } 20
$$

22 وهذا الخطأ مستشنع من رجل هو من دعاة "التاريخية" وأنصار المنهج التاريخي من جهة، وهو من المختصين ب"النص" مفهوماً وتأويلا

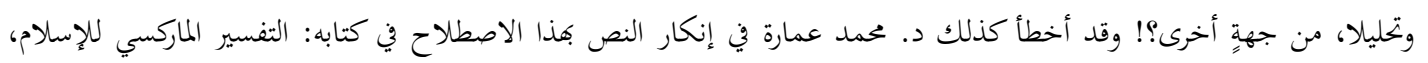

$$
23
$$

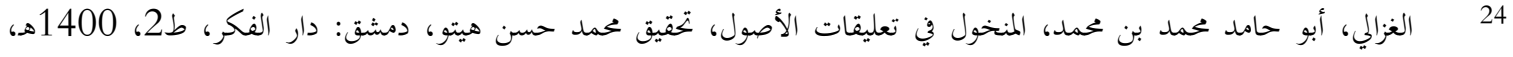
ص

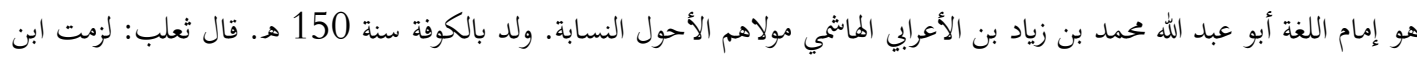

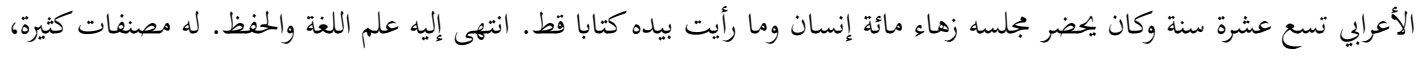


مالك (ت 179هـ) في الموطأ27 فلعل ابن الأعرابي، إذ ذكر هذا المعنى للنص، لاحظ بعض الاستخدام له من قبل بعض علماء عصره.

ومنها: هذه الحكاية التي يرويها الجصاص عن داود الظاهري (ت 270ه) قال: "حكى داود الأصبهاني أن إسماعيل (ت 282هـ) سُئل عن "النص"، ما هو؟ فقال: النص: ما اتفقوا عليه، فقيل له: فكل ما اختلفوا فيه من الكتاب فليس بنص؟ فقال: القرآن كله نص. فقيل له: فَلِمَ اختلف أصحاب محمد النبي، صلى الله عليه وسلم، والقرآن كله نص؟... قال داود: ظلمه السائل؛ ليس مثله يُسأل عن هذه المسألة، هو أقل من أن يبلغ علمه هذا الموضع."

تُظهر هذه الحكاية أن إسماعيل القاضي قد انقطع عن الإجابة لَمَّا نُقضض عليه تعريفه للنص بأنه ما

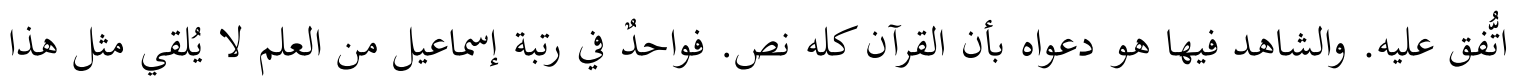

وكان صاحب سنة واتباع، مات بسامرا في سنة 231 هـ انظر : الذهبي، أبو عبد الله عمد بن أممد، سير أعلام النبلاء، تحقيق شعيب

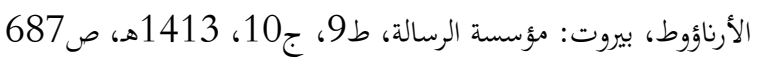

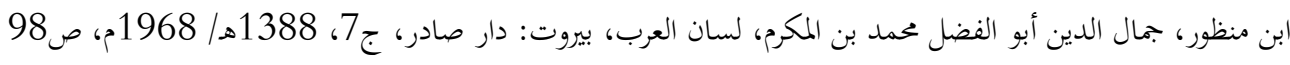

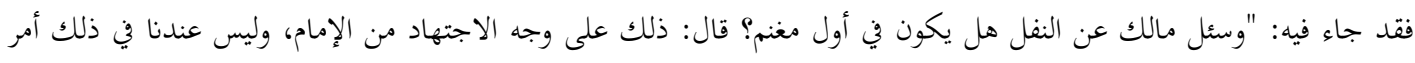
26

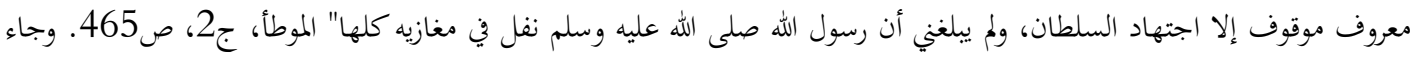

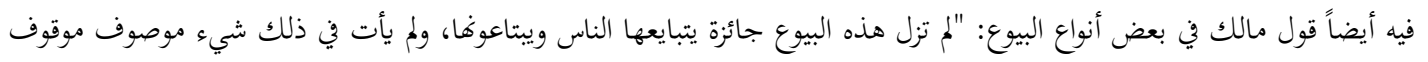

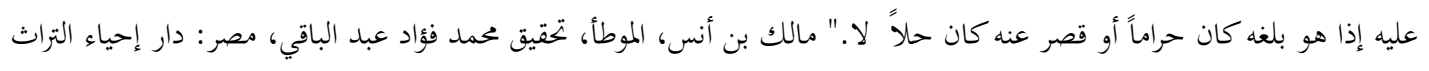

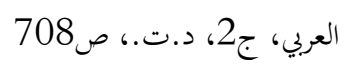
والغريب أن د. نصر أبو زيد قد أورد هذا المعنى -التوقيف- ضمن المعاني الاصطاحية للنص، لكنه لم ينتبه إلى ما هو معنى التوقيف،

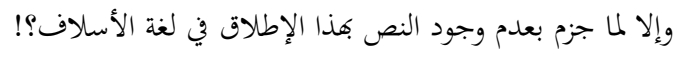

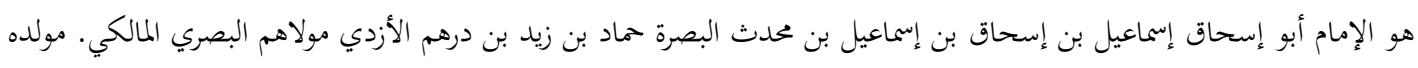

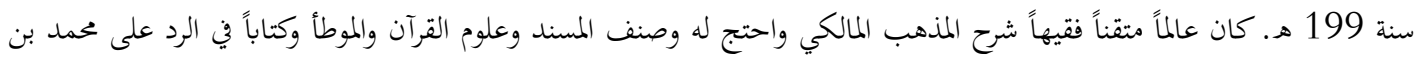

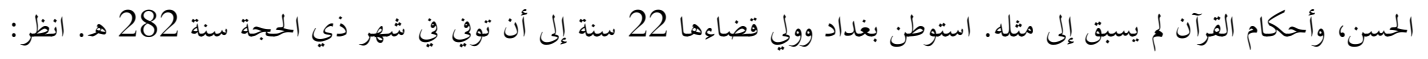

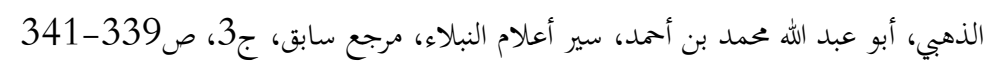

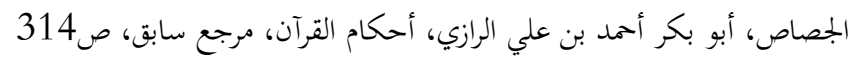


الكلام على عواهنه حتى ينقطع بهذه السهولة، فلعل له وجهة نظر 31 في دعواه هذه لم يذكرها داود الظاهري عمدا، فقد كانت بينهما عداوة وشحناء كما قال الجصاص. 32 والله أعلم. أما عن كيفية تطور لفظ النص من المعنى اللغوي إلى هذا المعنى فثمة -و الله أعلم- احتمالان.

الأول: هو أن النص بدأ يُطلق، بصيغة الفعل أو المصدر، على عزو الحديث إلى قائله بمعنى رفعه إليه، ثم شاعت هذه اللفظة في علم الرواية كما دل عليه كلام عمرو ابن دينار (ت 126ه): "ما رأيت أحداً أنصَّ للحديث من الزهري،"33 وقول أبي سلمة بن عبد الرمن (ت 94هـ أو 104هـ) وأبي عبد الله الأغر المعاصر له، ضمن حديث روياه عن أبي هريرة موقوفا لأفما نسيا مراجعة أبي هريرة في رفعه: "فذكرنا ذلك له والذي فرطنا فيه من نصِّ أبي هريرة له" أي فرطنا من الاستيثاق من رفع أبي هريرة الحديث إلى النبي، صلى ركل الله عليه وسلم. 34

وبعد ذلك صار يُطلق النص، عن طريق علاقة التلازم بين الفعل والمفعول، لا على عملية العزو أو الرفع فحسب، بل وعلى الكلام المعزو أو المرفوع أو المنصوص نفسه، أي كلام الشارع كتاباً أو سنة.

والاحتمال الثاني: هو أن النص -كما قلنا- كان يدل على الرفع وبالتالي الظهور واستخدم الفقهاء والأصوليون، لاسيما المتقدمين، هذه اللفظة بمعنى الظاهر، وكثر إطلاقهم إياها على كلام الشارع كتابا أو

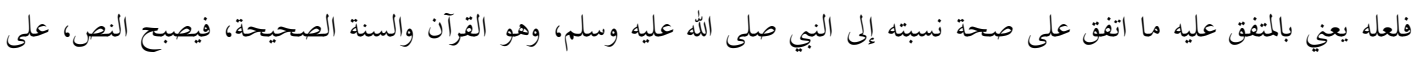

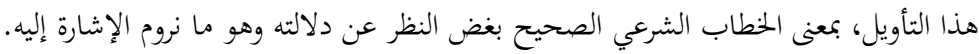

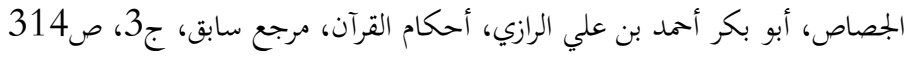
32

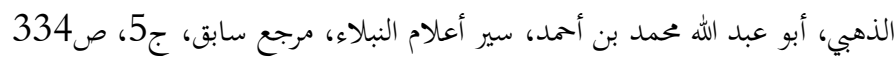
33

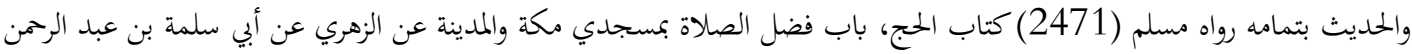

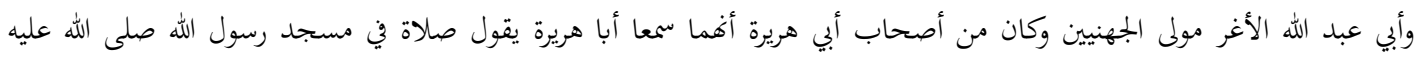

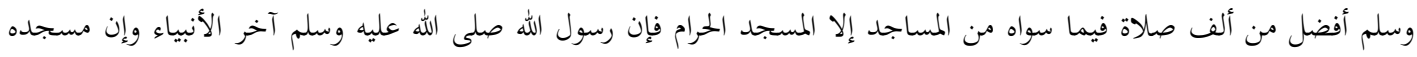

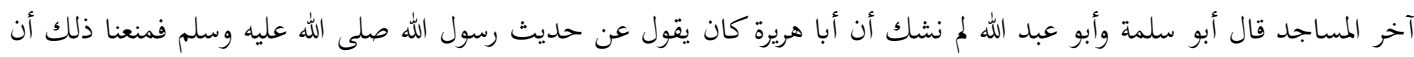

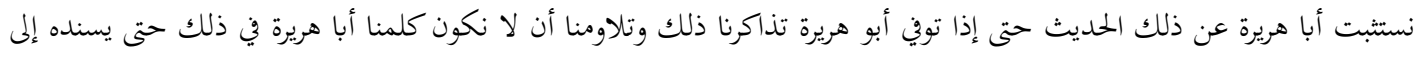

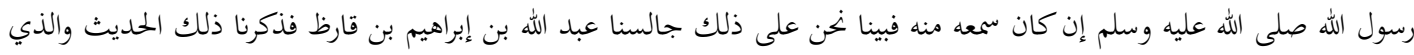
فرطنا فيه من نص أبي هريرة عنه فقال لنا عبد الله بن إبراهيم أشهد أني سمعت أبا هريرة يقول قال رسول الله صلى الله عليه وسلم فإني

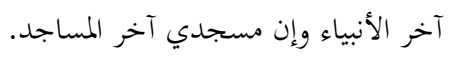


سنة، حتى صارت عند التجرد مرتبطة بهما، وصار يُعبر عن الخطاب واضح الدلالة بـ "النص" بجرداً. ثم لما كان غالبُ ما روي في الشرع نصوصاً واضحة عُمم الإطلاق على كل كلام الشارع اعتبارا للغالب. وهذا هو تخمين عبد العزيز البخاري والكفوي. 35 والله أعلم.

ثانياً :المعاني الاصطلاحية التي تستهدف بالنص الخطاب ذاته

وهي ثلاثة اصطلاحات:

\section{الاصطلاح الأول:}

يُطلق فيه النص على: الخطاب الشرعي سواء أكان من الكتاب أو السنة.

ومن التعريفات التي أوردها الأصوليون لـ "النص" بهذا المعنى ما يلي:

النص هو: "جرّد لفظ الكتاب والسنة" حكاه ابن دقيق العيد، 36 والزركشي، 37 وذكرا أن هذا هو

اصطلاح الجدليين. أو هو: "اللفظ الوارد في القرآن أو السنة المستدَّل به على حكم الأشياء" كما يقول ابن حزم الأندلسي. 38 أو هو: "ما دلّ على معنى كيفما كان، وهذا هو الغالب في كلام الفقهاء في الاستدلال، حيث يقولون: لنا النص والمعنى، ودل النص على هذا الحكم" حكاه ابن بدران الدمشقي، 39 وحكى قريباً منه القرافي المالكي.

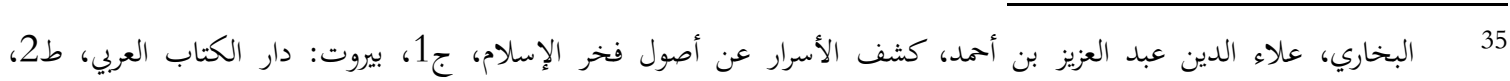

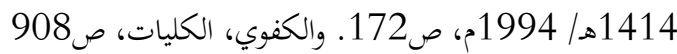

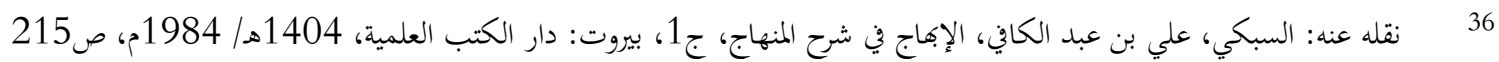

$$
\begin{aligned}
& 37
\end{aligned}
$$

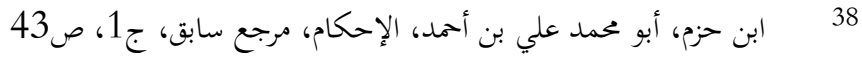

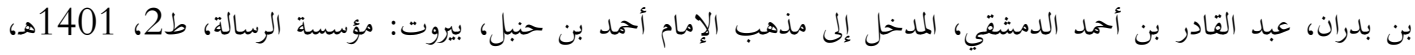$$
\text { ص187 }
$$$$
\text { القرافي، شهاب الدين أبو العباس أحمد بن إدريس الصنهاجي، شرح المحصول، مرجع سابق، ج5، ص2275 }
$$ 
وقال أبو الحسين البصري: "قولنا: نص، في عُرف الفقهاء، يقع على نص الله، عز وجل، ونص رسوله صلى الله عليه وسلم." 41 أو هو "كل سمعي كتاباً أو سنة" حكاه الأنصاري. 42 أو هو: "الكتاب والسنة"، حكاه الغزالي، 43 والتفتازاني، 44 والبركتي، 45 والكفوي. 46 أو هو - كما يقول أبو مجتى_47 "الكتاب الكريم والسنة الشريفة بأقسامها الثلاثة: قول المعصوم، صلى الله عليه وسلم، وفعله، وتقريره."

ولنا حول هذا الاصطلاح وحول ما أورده الأصوليون في شأنه الملاحظاتُ التالية:

الملاحظة الأولى: أن النص هذا الاصطلاح هو الأكثر شيوعاً في الدلالة على لفظ الكتاب والسنة من مصطلح "الخطاب"، وذلك عند الفقهاء والجدليين. أما في اللغة الأصولية فمصطلح "الخطاب" هو الأكثر رواجاً عند أوائل الأصوليين ومتقدميهم، أما عند المتأخرين فقد صار مصطلح النص يزاحم مصطلح الخطاب، وإن استمرت الغلبة لهذا الأخير.

ومما يجدر قوله هنا إن مصطلحي النص الشرعي والخطاب الشرعي، وإن كانا مترادفين في الدلالة على لفظ الكتاب والسنة إلا أن الترادف بينهما ليس تاماً، وذلك من جهات: إحداها: أن "النص"، من الناحية اللغوية، لا تُشترط له المواجهة، أي وجود المتكلم والمخاطب في الوقت نفسه. أما "الخطاب"، فتشترط له المواجهة لغة. وعلى القول بأزلية الكتاب ينخرم هذا الشرط، ومن هنا دار جدل كبير بين الأصوليين حول جواز وعدم جواز مخاطبة المعدوم. 48 والجهة الثانية: أن "الخطاب" يتضمن، عند كثير من الأصوليين، جميع أبو الحسين البصري، محمد بن علي بن الطيب، المعتمد في أصول الفقه، تحقيق خليل الميس، بيروت: دار الكتب العلمية، ج2، ص420

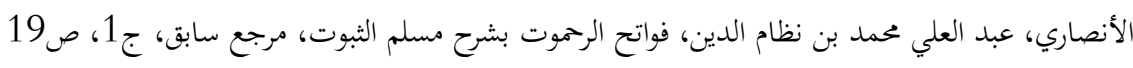
42 43

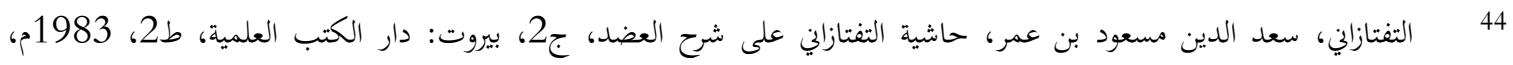
ص187

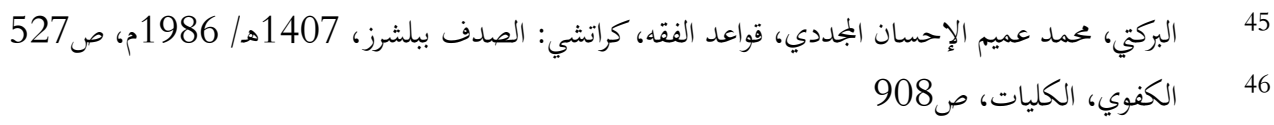

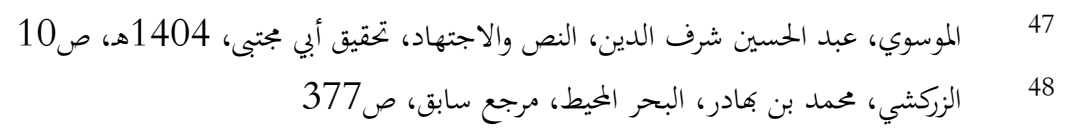


الأدلة المعتبرة شرعا من كتاب وسنة وإجماع وقياس واستحسان وغير ذلك. 49 أما النص فلا يتضمن إلا دليلي الكتاب والسنة. والجهة الثالثة: أن بعض الأصوليين يستني من الخطاب "الفعل النبوي" بينما هو داخل في

$$
\text { النص. قال أبو الحسين البصري: "الدلالة الشرعية ضربان: }
$$

خطاب: وهو خطاب الله، وخطاب رسوله، صلى الله عليه وسلم، وخطاب الأمة (= الإجماع)...

$$
\text { وغير خطاب: وهو الأفعال، والقياس، والاستنباط."50 }
$$

وبهذا نجد أن مصطلح النص أدق في التعبير عن الكتاب والسنة من مصطلح الخطاب، ولذا فنحن نفضله عليه في هذا المجال. ولن نتابع ما قاله الغزالي بعدما عرف النسخ بأنه "الخطاب الدال على ارتفاع الحكم الثابت بالخطاب المتقدم... "، قال: "وإنما آثرنا لفظ الخطاب على لفظ النص (أي: في تعريف النسخ) ليكون شاملاً للفظ والفحوى والمفهوم وكل دليل إذ يجوز النسخ بكل ذلك"، 51 لأنه قاله تقليداً، بل نقلاً حرفياً، عن الباقلاني الذي يقُصُر النص - كما سنوضحه لاحقاً-على الدلالة المنطوقة، ويُخرج عنه الدلالة الالتزامية كالفحوى والإشارة والمفهوم المخالف، بخلاف الخطاب. وهو اصطلاحُ لم يساعده عليه أحد حتى الغزالي نفسه عندما تعرض لتعريف النص، فلا أدري كيف وافقه الغزالي هنا وخالفه هناك؟!

ومن هنا عرفوا الحكم الشرعي بأنه خطاب الله تعالى المتعلق بأفعال المكلفين ....الخ، والحكم يثبت بجميع الأدلة الشرعية من كتاب وسنة

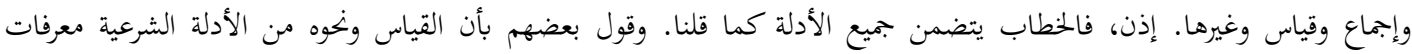

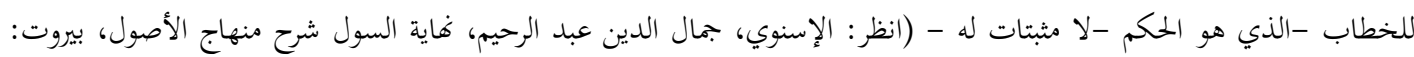

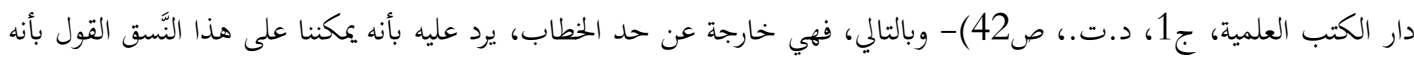

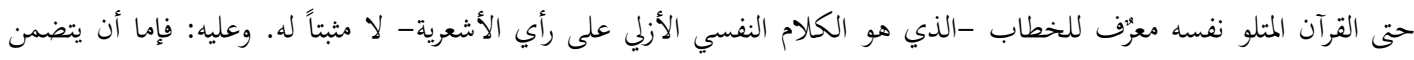

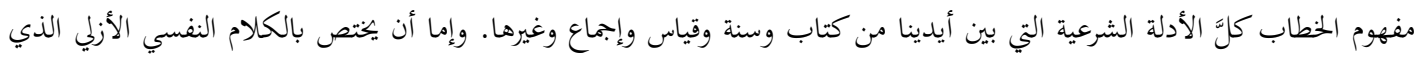

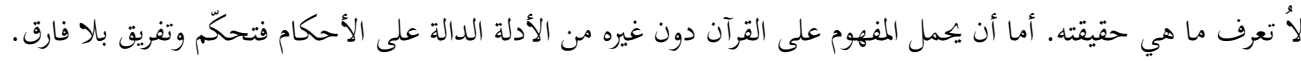

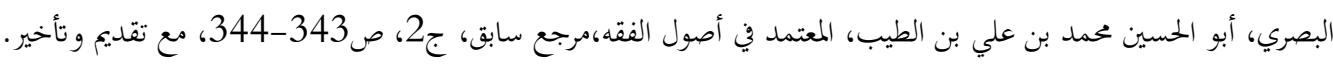


الملاحظة الثانية: إبان تعرضهم لتعداد الاصطلاحات التي يتناوها النص، لم يذكر جمهور الأصوليين لا سيما عند التعريف بالنص والظاهر - من المتقدمين أو المتأخرين بل حتى المحدثين 52 هذا الاصطلاح. وهذا مستغربٌ جداً. وإن كنت أعزوه إلى شيء فإنما أعزوه إلى تأخر فشّو استخدام هذا الاصطلاح في الكتابة الأصولية عن باقي الاصطلاحات، كما سنبين لاحقاً.

فإن قيل: هذا تعليل لعدم تطرّق المتقدمين للتعريف به لأفم لم يستخدموه إلا في النادر، فما بال المتأخرين لم يذكروه مع فشّّ استخدامهم إياه في بجاري كلامهم؟ فالجواب هو أن ذلك -والله أعلم- بسبب طغيان التقليد والنقل عن المتقدمين في تصانيف غالب المتأخرين حتى أنساهم ذلك رصْد تطور المصطلح الذي شاع في كتابتهم هم أنفسهم، فالمقلد أو الناقل يعيش

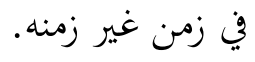

الملاحظة الثالثة: ما ذكره ابن دقيق العيد والزركشي -كما أوردناه آنفاً- من أن النص بهذا الاصطلاح هو اصطلاح الجدليين، إذا كان المراد اختصاص الجدليين به، وهو الظاهر، فكلامُ تنقصه الدقة؛ إذ لم يختصَّ بـ "النص" هذا الإطلاق أحد، وإنما هو فاشٍ في كتابة الأصوليين -لا سيّما المتأخرين- والفقهاء والجدليين على حد سواء. وإذا كان المقصود غلبةً استعماله في لغتهم فالأمر قريب. الملاحظة الرابعة: ما قاله القرافي وابن بدران من أن النص هو "ما دل على معنى كيفما كان" قد يؤخذ منه أهما يدخلان قيد الدلالة في تعريف النص بهذا الإطلاق، وبالتالي يُخرجان النصوص غير الدالة بنفسها - كالنصوص المجملة والمتشاهةة- من حد النص. وهذا ما لا نعتقد أغم قصدوه، وذلك لسببين: أحدهما أن النص بهذا الإطلاق لم يجر عليه أحد، مع أن القرافي وابن بدران كليهما كانا في صدد توصيف المصطلح في لغة الأصوليين لا بصدد ابتكار دلالة خاصة لهذا المصطلح.

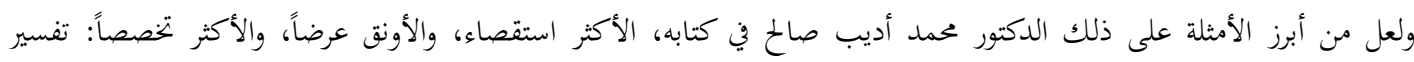

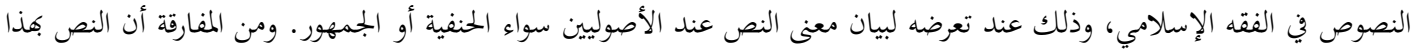
الاصطلاح مستخدم في عنوان الكتاب نفسه (تفسير النصوص)؛ 
والسبب الآخر: تعقيب ابن بدران بقوله "وهذا هو الغالب في كلام الفقهاء في الاستلال، حيث

يقولون: لنا النص والمعنى"، 53 والغالب في كلام الفقهاء في الاستدلال هو أن النص هو مجرد لفظ الكتاب والسنة بغض النظر عن نوع الدلالة. والنص عندهم هو اللفظ الذي يجعلونه في مقابلة "المعنى"، أي القياس. وربما قالوا: "المنقول والمعقول"، بدل "النص والمعنى."

الملاحظة الخامسة: النص هذا الإطلاق هل يشمل الفعل النبوي؟ هنا ثمة بجال للاجتهاد، وما نرجحه هو أنه يشمله لأفم أطلقوا النص على الكتاب والسنة، والفعل النبوي من السنة. لكن يُشكل على ذلك أنه لا يسوغ لغة أن يوصف الفعل بأنه نص. قال أبو الحسين البصري، بعد أن اشترط في النص أن يكون

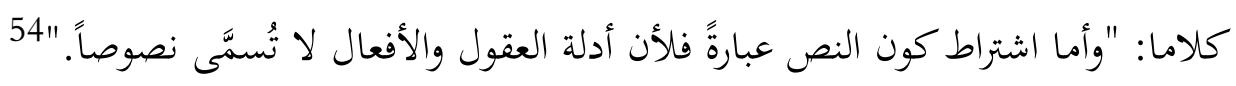

والجواب على هذا الإشكال أن الفعل النبوي لم يدخل في مفهوم النص إلا بعد أن تحول من صيغته الفعلية إلى الصيغة الكلامية على لسان الصحابة، رضوان الله تعالى عليهم. فالفعل النبوي كان على صيغته الفعلية في عهد الرسالة فقط حيث كان يُدرك بالمشاهدة، أما بعد عصر الرسالة فقد صار كلاماً للصحابة يدرك بالسماع فحسب. ومن هنا صح بأن يوصف بأنه نص، لكنه، في الحقيقة، ليس "نصاً للشارع"، بل "نص عن الشارع" صلى الله عليه وسلم. الاصطلاح الثاني : n ويُطلق فيه النص بمعنى "حكاية اللفظ على صورته، كما يُقال: هذا نَصُُ كلام فلان"، وهذا نص كلام الزركشي. 55 وقال ابن حزم: "وقد يُسمَّى كل كلام يُورد كما قاله المتكلم به نصاً." ولنا هاهنا ملاحظتان: إحداهما: أن مصطلح النص في هذا الإطلاق لا يُلفظ مجرداً بل مقيداً بالإضافة إلى القائل، أي أنه لا يقال: "النص" هكذا بـ "أل" التعريف، كما هو الحال في الاصطلاح السابق، وإنما 53 ابن بدران، عبد القادر بن أممد الدمشقي، المدخل إلى مذهب الإمام أممد بن حنبل، بيروت: مؤسسة الرسالة، ط2، 1401هـ، ص187

$$
\begin{aligned}
& 54 \\
& 55
\end{aligned}
$$

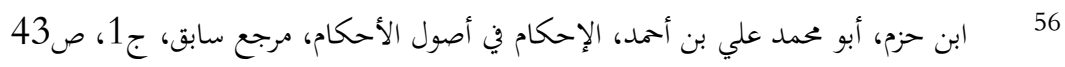


يُقال: هذا نَصُُ كلام فلان بالإضافة إلى القائل، أو يُقال: نَصَّ فلانُ على كذا بصيغة الفعل. ولا يُستغنى عن الإضافة إلا إذا دلت القرينة عليها. الملاحظة الثانية: لا بد من الأخذ بعين الاعتبار أن الأصوليين كثيرا ما يتجوَّزون في هذا الإطلاق لا سيما حالة إيراد النص بصيغة الفعل، فيقولون: نَصَّ فلان على كذا ويوردون معنى كلامه لا كلامَه بحروفه، ولا يخفى هذا الأمر على متتبع.

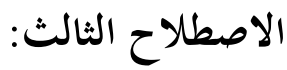

يُطلق فيه النص على "نص الشافعي، فيقال لألفاظه نصوص باصطلاح أصحابه كافة"، 57 فيقولون: هذا الحكم حكاه فلان عن النص، ويجب كذا على النص، وهذا بخلاف النص. ويقصدون في ذلك كله كلام الإمام الشافعي رحمه الله تعالى. وليس هذا الاصطلاح إلا نوع تخصيص للذي قبله. فلعله كان يُقال

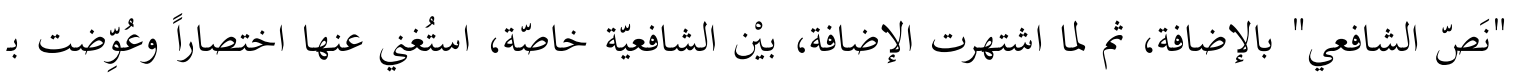
"أل" التعريف فصار يُقال: "النص" مجرداً، والله أعلم.

هذه هي المعاني الاصطلاحية الثلاثة التي أطلقت بإزاء النص بحيث جعلته يقابل لفظاً ما بغض النظر عن دلالة هذا اللفظ. وهذا اللفظ كما رأينا هو:

$$
\begin{aligned}
& \text { إما لفظ الكتاب والسنة. وإما لفظ كل قائل بحروفه. } \\
& \text { وإما لفظ الإمام الشافعي خاصة. }
\end{aligned}
$$

وحان الوقت الآن لنبدأ بالقسم الثاني من المعاني الاصطلاحية التي تقابل النص بوصفه لفظاً ذا دلالة من نوع خاص.

ثالثاً :المعالي الاصطلاحية التي تستهدف بالنص خطابا ذا دلالة معينة

$$
\begin{array}{r}
\text { وهذه الاصطلاحات سبعة هي: } \\
\text { الاصطلاح الأول: }
\end{array}
$$

$$
57 \text { }
$$


يُطلق النص فيه على الخطاب أو اللفظ واضح الدلالة على الحكم أو المعنى. أي على ما كان يدل على الحكم أو المعنى قطعا أو في غالب الظن. ويخرج بهذا القيد الخطاب ذو الدلالة الغامضة -المجملة أو المشتركة أو المؤولة- بالنسبة إلى الحكم أو المعنى الذي هو غامضُ فيه. ويمكننا تصنيف تعريفات الأصوليين الدالة على هذا المعنى في أربع بجموعات: الجمموعة الأولى: وتضم: قول الشافعي: "النص: كل خطاب عُلم ما أُريد به من الحكم."58 وقول

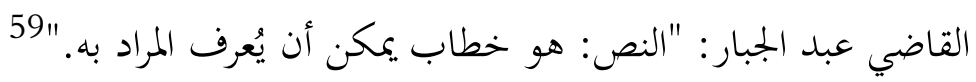
والملحوظ في حد النص عند هذين الإمامين هو تركيزها على مجرد أن يكون اللفظ معروف المعنى، سواء أكان مَرَدُّ هذه المعرفة إلى اللفظ نفسه أو إلى قرائن خارجية. أي أن النص يشمل اللفظ الواضح بنفسه أو الواضح بغيره. وبناءً على هذا لا يخرج عن حد النص إلا الألفاظ المجملة قبل البيان، والألفاظ المتشاهة التي استأثر الله تعالى بعلم معناها عند من يفسر التشابه بهذا المعنى. وممن كان يذهب إلى هذا التوسع في مفهوم النص الإمام أبو الحسن الكرخي رحمه الله تعالى، قال الجصاص: كان أبو الحسن الكرخي يقولُ "في اللفظ المحتمِل لضروبٍ من التأويل: إنَّ من قامت له الدلالة على بعض المعاني أنه هو المراد جاز له أن يقول: إن هذا نص عندي. وكذلك إذا رُويَ ذلك التأويل عن رسول الله، صلى الله عليه وسلم، فجائزّ أن يُقال: إنّ

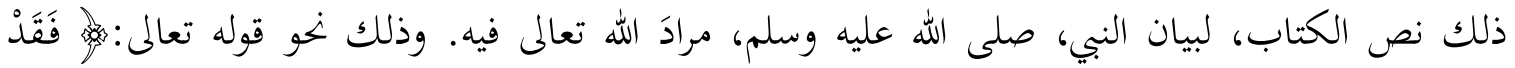

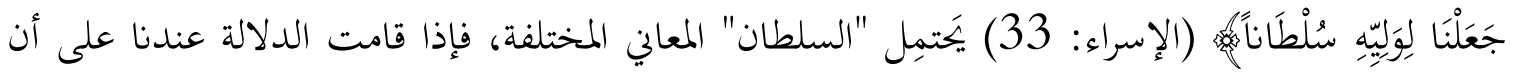
المراد به القود (= القصاص) جاز أن يقول: قد نصت هذه الآية على إيجاب القود لولي المقتول ظلماً."60 وقال ابن بدران معللاً ذلك وموضحاً له: "وقد يُطلق (النص) على ما تطرق إليه احتمال يعضُده دليل؛ لأنه

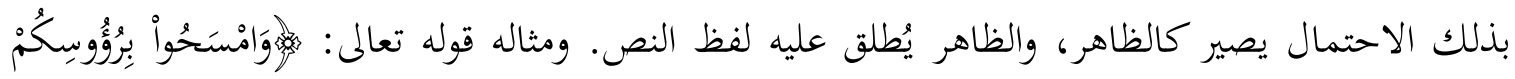

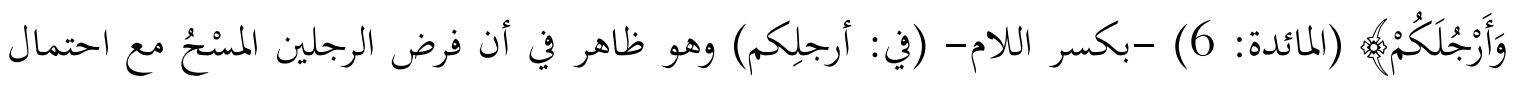

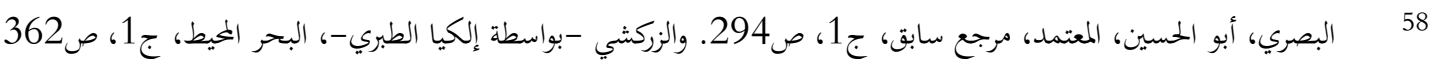

$$
\begin{aligned}
& 59 \\
& 60
\end{aligned}
$$


الغسل، فاحتمال الغسل مع الدليل الدال عليه (وهو فعله، صلى الله عليه وسلم، في وضوئه) يُسمى نصا لأنه صار مساويا للظاهر في المسح وراجحاً عليه، حتى إنه يجوز لنا أن نقول: ثبت غسل الرجلين

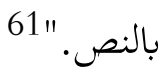

الجموعة الثانية: وتضم: قول أبي البركات ابن تيمية: النص هو: "القول الذي يفيد بنفسه ولو ظاهرا،

$$
\text { وهذا منقول عن الشافعي وإمامنا (= أحمد) وأكثر الفقهاء." }
$$

وقول الجصاص: "كل ما يتناول عينا مخصوصة بحكم ظاهر المعنى بيّن المراد فهو نص."63

وقول عبد العزيز البخاري: النص هو: "كل ملفوظ مفهوم المعنى من الكتاب والسنة، سواء أكان

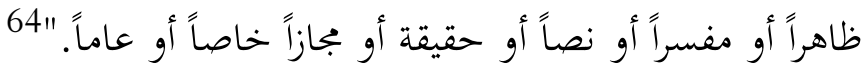

والملحوظ في حد النص عند هؤلاء الأئمة هو تركيزهم، نوعاً ما، على الوضوح الذاتي للفظ النص. وعليه لا يدخل في إطلاق النص عندهم اللفظ الواضح بغيره كما هو الحال في تعريفات المجموعة الأولى. ومما قد يسترعي الانتباه هنا اختلاف النقل عن الإمام الشافعي في تعريف النص هذذا الإطلاق، فبينما ذكر إلكيا الطبري وأبو الحسين البصري أن الشافعي عرفه بكونه: "خطاب يُعلم ما أريد به من الحكم" وزاد أبو الحسين

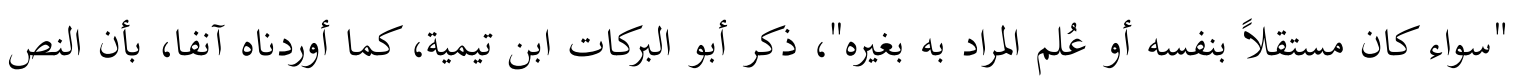

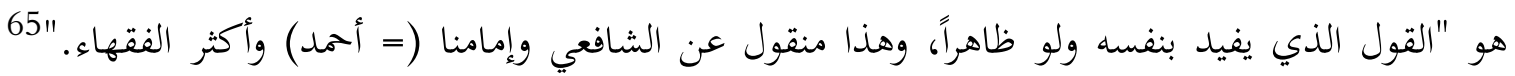

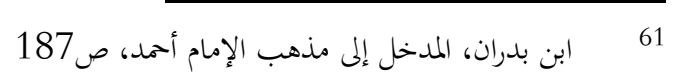

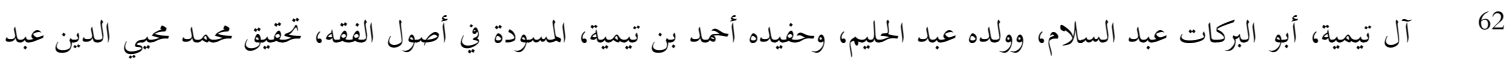

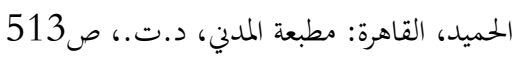

$$
63
$$$$
64
$$

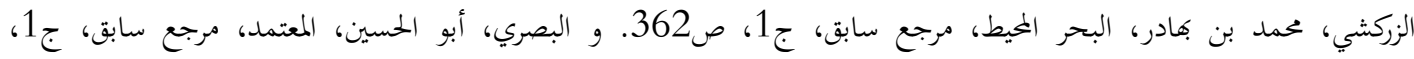

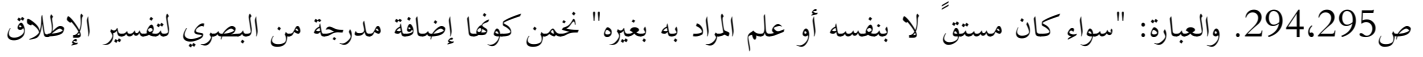

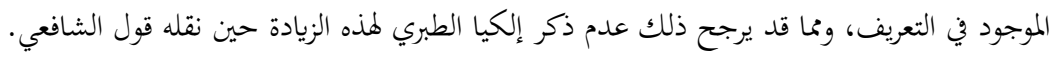


فَقَصَر النص على ما أفاد بنفسه دون ما أفاد بغيره. 66 وما نرجحه هو النقل الأول لأن أبا البركات حنبلي وإلكيا والبصري شافعيان وأهل مكة أدرى بشعاهما.

الجمموعة الثالثة: وتضم: قول الأستاذ أبي منصور البغدادي: "والصحيح في حدّ النص عندنا: أنه الدال على الحكم باسم المحكوم فيه، سواء كان ذلك النص محتمِلاً للتأويل والتخصيص أو غير محتمل."67 وقول تقي الدين ابن تيمية: النص: هو "ألفاظ الكتاب والسنة سواء كانت دلالته قطعية أو ظاهرة."68 ومما نلحظه في هذين التعريفين هو تركيز صاحبيه على نفي اقتصار النص على الألفاظ قطعية الدلالة، أو غير المحتملة، بل هو يشمل بالإضافة إليها الألفاظ الظاهرة المحتمِلة، كالعام في دلالة على الاستغراق، والمطلق في دلالنه على الإطلاق، وغير ذلك من الدلالات المختملة.

الجموعة الرابعة: وتضم: قول العكبري الحنبلي: النص هو: "ما كان صريهاً في حكم من الأحكام،

وإن كان اللفظ محتملاً لغيره."69 وقول ابن دقيق العيد: النص: "هو اللفظ الذي دلالنه قوية الظهور."70 والملحوظ على حد النص هنا هو اشتراط، "الصراحة" بتعبير العكبري أو "قوة الظهور" بتعبير ابن دقيق العيد في دلالة اللفظ على المعنى، والصراحة وقوة الظهور بمعنى واحد فيما نرى. وعلى هذا لا يشمل النص هذا الإطلاق كل ظاهر أو واضح بل ما بلغ القطع أو كاد. ولذلك لا يقال بأن العام نص في الاستغراق وأن الأمر نص في الوجوب؛ لضعف ظهور العام في الاستغراق؛ إذ ما من عام إلا وقد خصص كما قيل، ولضعف دلالة الأمر على الوجوب؛ لأنه قد يصرف إلى الندب بأدنى قرينة. وهذا الاشتراط معقول، وقد بلغ ابن دقيق العيد شأوا بالغاً في التحقيق. ولعله لاحظ هذا القيد من خلال استقرائه لكلام متقدمي الفقهاء والأصوليين.

66 67 آل تيمية، أبو البركات عبد السلام، وولده عبد الحليم، وحفيده أحمد ابن تيمية، المسودة في أصول الفقه، مرجع سابق، ص513، 67

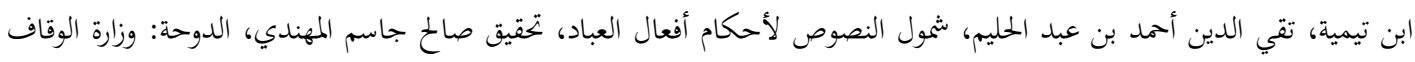

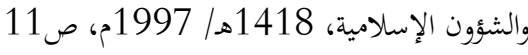
69

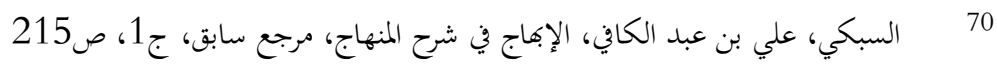


إن التعريفات السابقة بشتى مجموعاةًا، وإن تباينت نوعاً ما في بعض القيود، إلا أها تشترك في كون الشرط الأساس في النص هو وضوح الدلالة بغض النظر عن كون اللفظ محتملاً أم لا. وأكثر الأصوليين يستخدم هذا المعنى لمصطلح النص -أعني اللفظ الواضح في معناه- في باب القياس، وذلك عند حديثهم عن مسالك العلة فيذكرون في مقدمتها مسلك النص، ويعنون بهذا المسلك ما قاله الرازي: "نعنى بالنص: ما تكون دلالته على العلّية ظاهرة سواء كانت قاطعة أو محتملة: أما القاطع فما يكون صريحا في المؤثرية وهو قولنا: لعلة كذا، أو لسبب كذا، أو لموجب كذا، أو لأجل كذا ... وأما الذي لا يكون قاطعاً فألفاظ ثلاثة اللام وإنَّ والباء." 71 وإذا تقرر هذا، فلا وجه لعدّ الزركشي هذا الإطلاق للنص في هذا الموضع من كتب الأصول، وهو كتاب القياس، اصطلاحاً خاصاً مبايناً لغيره من الاصطلاحات. وذلك حين قال: "ويُطلق (النص) باصطلاحات: ... الثاني: ما يُذكر في باب القياس وهو مقابل الإيماء."72

وقد ذهب أبو الحسين البصري إلى حد النص بكونه: "كلام تظهر إفادته لمعناه، لا يتناول أكثر مما قيل إنه نص فيه"73 زاعماً أنه بهذا التعريف قد ضمنه ثلاثة شروط:74 أحدها: كون النص كلاماً. والثاني: ظهور دلالته بنفسه. والثالث: "أن لا يدل على أفراده بطريق العموم؛ لأن الإنسان إذا قال لغيهه: اضرب

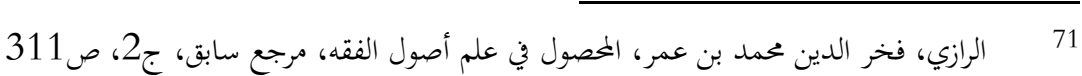

$$
\begin{aligned}
& 72 \\
& 73
\end{aligned}
$$

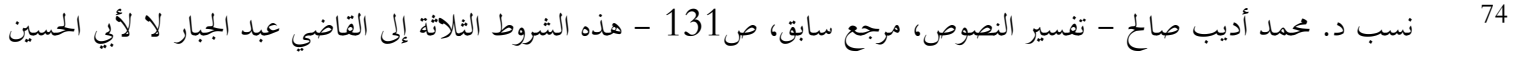

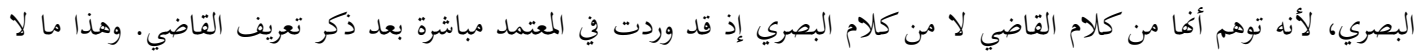

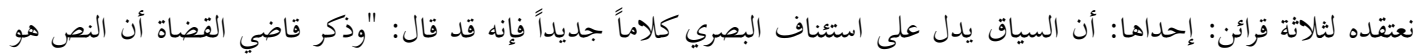
خطاب يمكن أن يعرف المراد به. واعلم أن النص يجب أن يشتمل على ثلاث شرائط أحدها أن يكون كلاماً....الخ" فانظر إليه كيف الثان

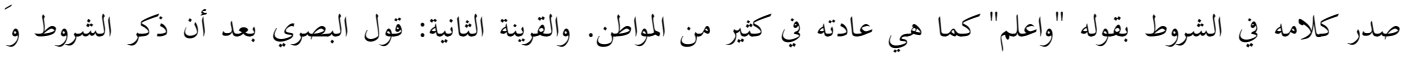

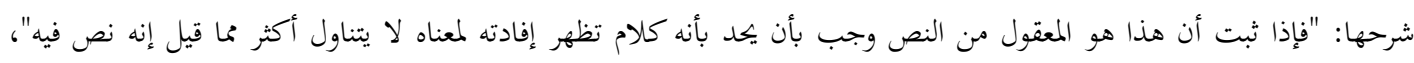

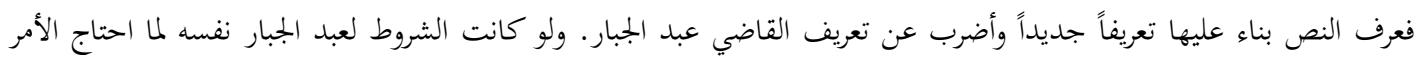

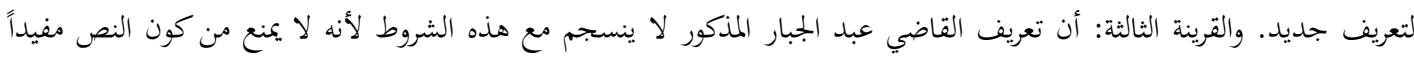

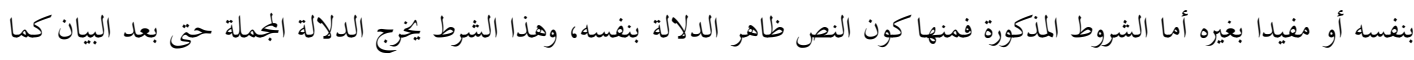

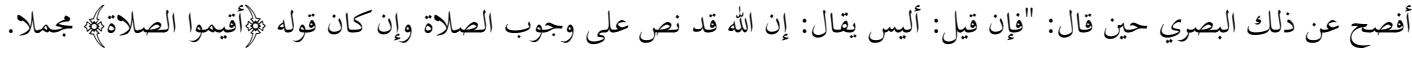

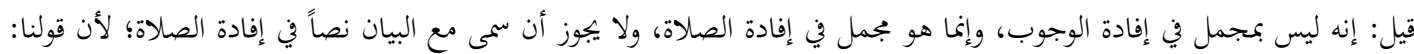

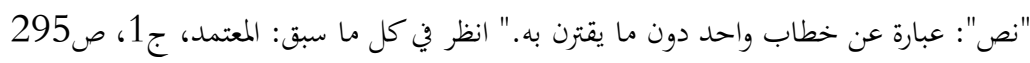


عبيدي لم يقل أحد: إنه قد نص على ضرب زيد من عبيده لمها أفاده وأفاد غيره. ويُقال: إن كلامه نص في

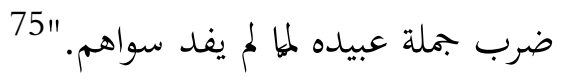

وهو .جذا الاشتراط لم يخرج بالنص عن كونه الخطاب واضح الدلالة على معناه. أما شرطه الأخير فمقصوده منه يحتمل أمرين: أحدهما: أن العام إذا أريد به الخاص فليس بنص في دلالته على هذا الخاص. وهذا مسلم لأن العام ظاهر في العموم مؤول في الخصوص كما هو رأي الجمهور. والدلالة المؤولة هي دلالة غامضة لا ظاهرة كما هو معروف. والأمر الثاني، وهو الراجح: أن دلالة العام على أفراده، لا جملة، وإنما فرداً فرداً، ليست هي من قبيل النص. ودلالة العام على فردٍ فرد من أفراده هي دلالة ظاهرة كما هو معروف لكنها ضعيفة الظهور لورود احتمال التخصيص بقوة، ولعل هذا هو ما دفع البصري إلى إخراجها من تعريف النص بمعنى الظاهر. ولعل البصري بهذا الشرط يرد على الحنفية قولم: "ما يتناوله العموم فهو نص...؛

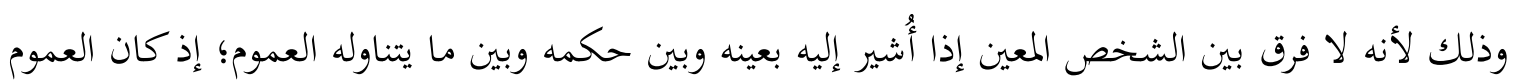
اسما لجميع ما تناوله وانطوى تحته. والمنصوص عليه ما نُص عليه باسمه. "76

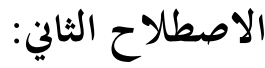

يُطلق فيه النص على الخطاب أو اللفظ ذي الدلالة القاطعة على الحكم أو المعنى.

ومعنى القطع: قطع الاحتمال، وبالتالي التأويل، وذلك كألفاظ الأعداد، فالحمسة لا تحتمل الأربعة ولا الستة، وكالفرس لا يحتمل الحمار ولا البعير.

وقد ذكر هذا الإطلاق كثيرٌ من الأصوليين: الباقلاني، 77 وإمام الحرمين، 78 وأبو إسحاق الشيرازي، 89 والأستاذ أبو منصور، 80 وأبو نصر القشيري، 81 وأبو حامد المروروذي، 82 والسبكي، 83 وابن دقيق العيد، 84

$$
76
$$

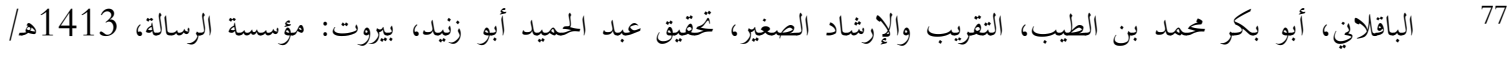

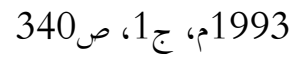

78 الجويني، عبد الملك بن عبد الله، البرهان في أصول الفقه، تحقيق عبد العظيم الديب، المنصورة: دار الوفاء، ط3، ج1، 1412هـ/

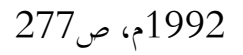


والزركشي، 85 والغزالي في المستصفى، والرازي، وابن رشد، والباجي، وأبو البركات ابن تيمية، وحفيده تقي الدين، والقرافي، وغيرهم كثير.

\section{ومن أقوالهم فيه:}

النص: هو "ما عَرَي لفظه عن الشركة، وخلص معناه من الشبهة." 86 أو هو "القطعي دون ما فيه احتمال."87 أو هو "ما لا يتطرق إليه احتمال أصلا لا على قرب ولا على بعد؟"88 أو هو "ما دل على ولى

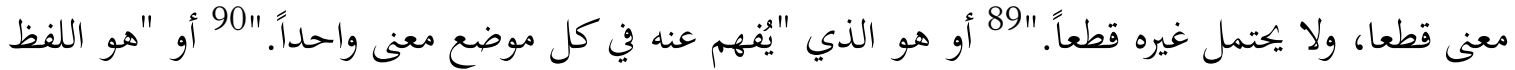
الذي لا يمكن استعماله في غير معناه الواحد." رُفع في بيانه إلى أبعد غاياته."

إن اللفظ المدّعى قطعيته بناء على هذا الاصطلاح أعم من أن يكون مفرداً أو مركباً. قال ابن رشد: "اللفظ - كما قلنا- يكون نصاً إذا فُهم عنه في كل موضع معنى واحداً، وهذا يوجد في المفرد والمركب. أما مثال المفرد فكالإنسان والفرس والحيوان، وأما المركب فمثل قوله تعالى:

$$
\begin{aligned}
& 79 \text { الشيرازي، أبو إسحاق إبراهيم بن علي، شرح اللمع، تحقيق عبد الجيد التركي، بيروت: دار الغرب الإسلامي، 1408هـ/ 1988م، }
\end{aligned}
$$

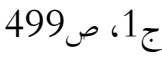

$$
\begin{aligned}
& 80 \\
& 81 \\
& 82 \\
& 83 \\
& 84 \\
& 85 \\
& 86 \\
& 8787 \\
& 88 \\
& 89
\end{aligned}
$$

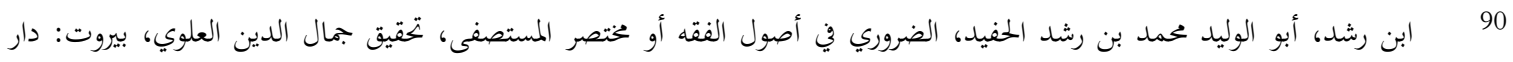

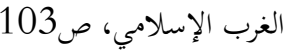

$$
\begin{aligned}
& 91 \\
& 92
\end{aligned}
$$

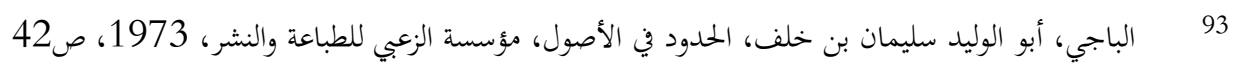


1)، وبالجملة كل ما تركب من المفردات النصوص، ولم تكن الضمائر فيه محتملة أن تعود على معنى أكثر من واحد."94 وبعض الأصوليين الذين قالوا بهذا الاصطلاح نظروا إلى دلالة اللفظ بجرداً، ومن هنا قالوا بـ "عزة النصوص" أي ندرة الألفاظ ذات الدلالة القاطعة. وهو الأمر الذي لم يلق قبولاً عند إمام الحرمين فأبطله على لسان الغزالي- في "المنخول" بالقول بأن ورود الاحتمال، غير المعتضِد بدليل، على اللفظ لا يسلبه

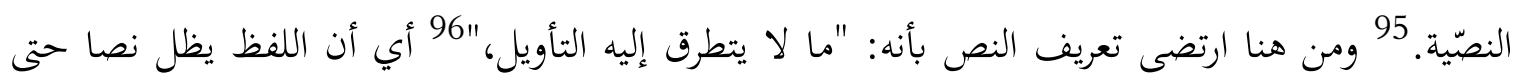
لو كان محتملاً ما لم يرد دليل يدعم هذا الاحتمال وحينئ يتطرق إليه التأويل. ثم أعرض عن هذا الجواب في "البرهان" وأبطل "عزة النصوص" بالقول بأن النصوص القواطع تكثر إذا ما نظرنا إلى القرائن المقالية والحالية التي تحتف بالألفاظ. أما الشاطبي فقد استغل القول ب "عزة النصوص" -ولم يعجبه القول بالقرائن كحل لهذه المشكلةليجعله، مع القول باشتراط توافر القطع في القاعدة الأصولية، إحدى أهم الدعائم لنظريته القائلة بضرورة استخدام "الاستقراء" للوصول إلى القطع. 98

وبعض الأصوليين، كالباقلاني، اقتصر في تعريف النص على اللفظ القاطع الذي يدل بمنطوقه دون ما

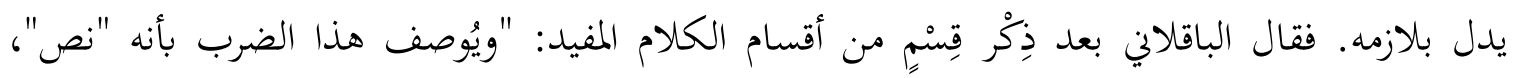
ومعنى وصفه بذلك ظهور معناه من غير احتمال، وكون المذكور فيه منطوقا باسمه الموضوع له، وفي التصريح

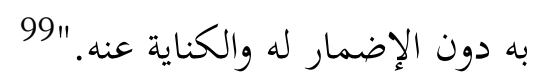

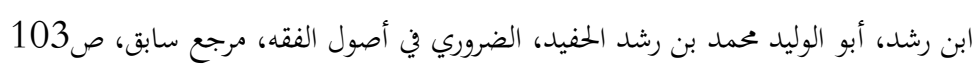

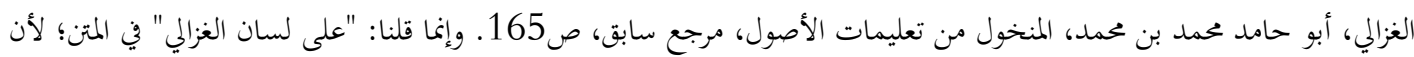

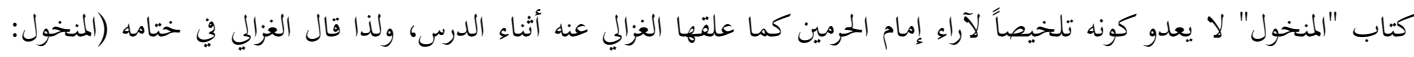

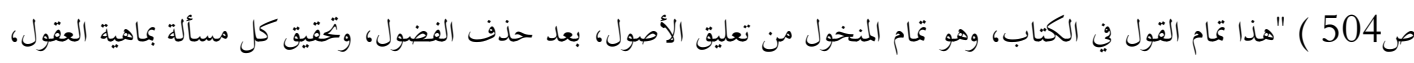

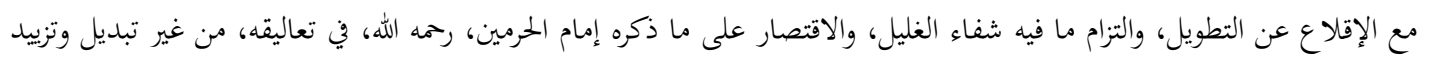

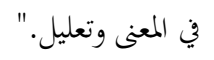

$$
\begin{aligned}
& 96
\end{aligned}
$$

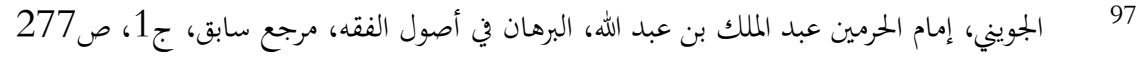

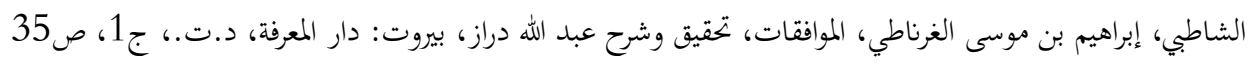

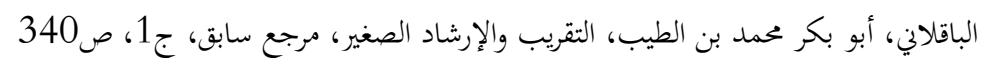


وما نراه هو أن الباقلاني تأثر بهذا الاختيار لمدلول النص بإطلاق للنص في لغة المتقدمين من الأصوليين والفقهاء لا سيما الإمام الشافعي، حيث شاع في لغته، المقابلة بين "النص" و"الدلالة": النص يعني به الملفوظ بعينه، والدلالة يعني بها ما سوى الملفوظ بعينه، كالمدلول عليه التزاماً، أو قياساً، أو بعموم

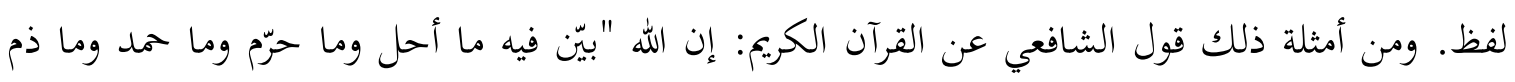

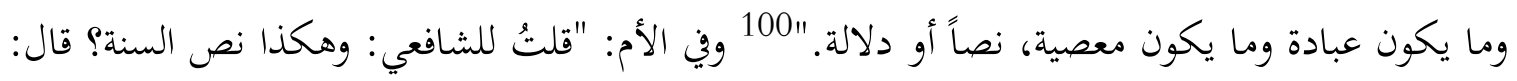
لا، ولكن هكذا دلالتها."101 وقال: "قلت: أفتجد في التنزيل سقوط الحد عنه؟ قال: أما نصاً فلا، وأما استدلالاً فنعم."102 وقال: "إن الله جل ثناؤه منَّ على العباد بعقول فدلهم بها على الفرق بين المختلف

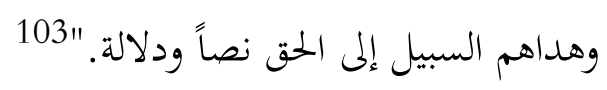

ولولا أن الباقلاني اشترط في النص بهذا الإطلاق أن لا يتطرق إليه الاحتمال لأصاب عين ما أراده الإمام الشافعي بالنص حين قابل بينه وبين الدلالة. فالشافعي وإن كان يطلق النص على اللفظ القاطع إلا أنه لا يقصره عليه بل يدرج معه الظني أو الظاهر، كما بيَّنا ذلك سابقاً. 104

وعلى أية حال فاشتراط الباقلاني في النص كونه دالا على معناه بطريق النطق لا بطريق الالتزام لم يجد قبولاً من أتباعه كإمام الحرمين والغزالي. فقال الإمام رادا على من رفض اعتبار دلالة الفحوى أو مفهوم الموافقة من قبيل النص لأغما دلالة التزامية لا مطابقية كما هو معروف: "الفحوى لا استقلال لها وإنما هي مقتضى لفظ على نظم ونضد مخصوص. قال تعالى في سياق الأمر بالبر والنهي عن العقوق والاستحثاث

$$
\begin{aligned}
& 100 \\
& 101 \\
& 102
\end{aligned}
$$

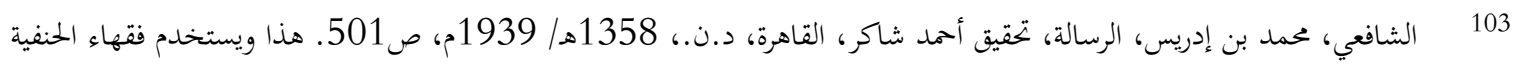

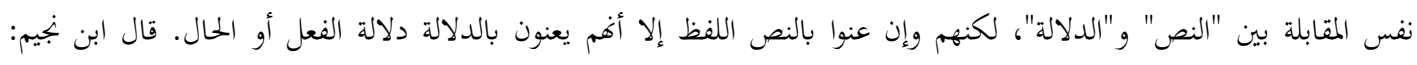

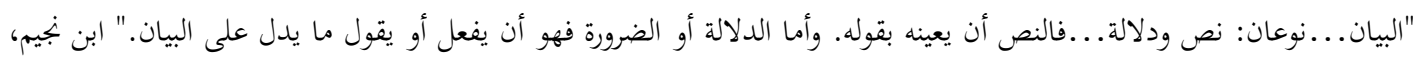

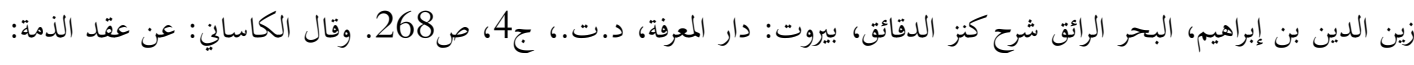

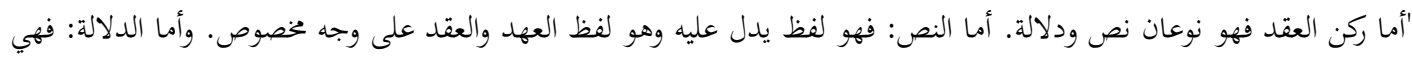

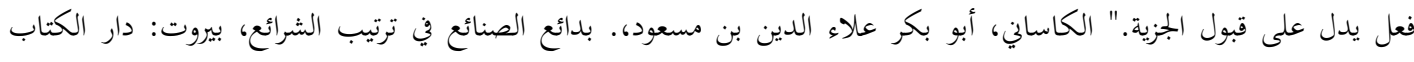

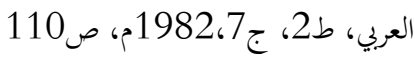

$$
\begin{aligned}
& 104
\end{aligned}
$$




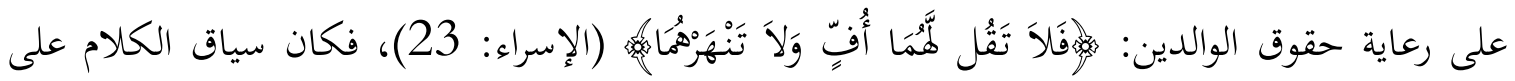
هذا الوجه مفيداً تحريم الضرب العنيف ناصَّا، وهو مُتلقى من نظم مخصوص، فالفحوى إذًا آيلةٌ إلى معنى الألفاظ." 105 وقال الغزالي: "النص ضربان: ضربٌ هو نصٌ بلفظه ومنظومه....وضربٌ هو نصٌّ بفحواه $106 "$ ومغهومهد. ويمكن النظر إلى مسألة دخول الدلالة الالتزامية تحت مسمى النص من جهتين: إحداهما: جهة الاستساغة اللغوية. والأخرى: جهة ضبط المصطلح. فأما من جهة الاستساغة اللغوية فنقول: إنه ينبغي التفريق بين نوعين من أنواع الدلالة الالتزامية القاطعة: المقصودة، وغير المقصودة. فالدلالة الالتزامية القاطعة المقصودة كمفهوم الموافقة تدخل في مفهوم

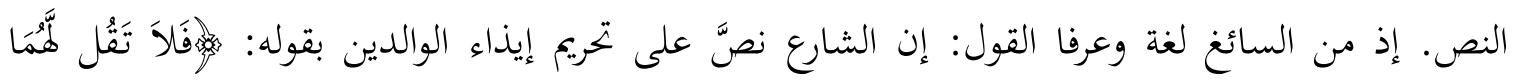

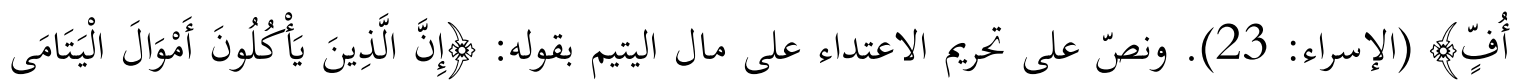

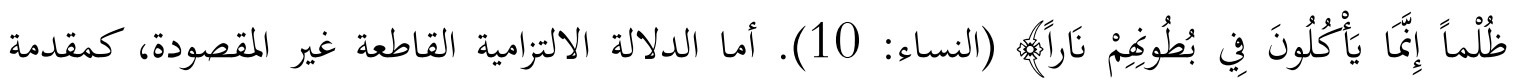
الواجب مثلاً، فإنها لا تدخل في مفهوم النص، إذ لا يسوغ القول إن الشارع نص على وجوب إحضار الماء

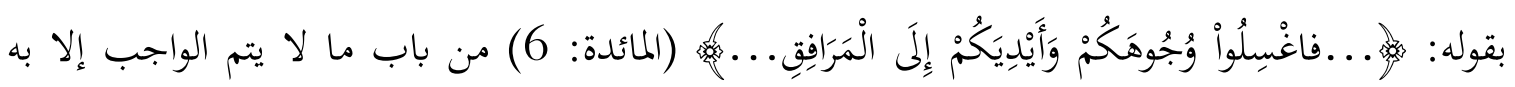
فهو واجب. وأما من جهة ضبط المصطلح فنقول: إن الدلالة الالتزامية تدخل في مفهوم النص سواء أكانت مقصودة أم لا بشرط كوها قطعية. والسير على هذا النهج في تفسير النص أيسر، وأوفق من ناحية عملية وإجرائية. إذ نقول اللفظ: إما أن يدل على المعنى قطعاً أو ظناً أو شكاً أو وهماً. فالمعنى المقطوع هو النص، والمظنون هو الظاهر، والمشكوك هو المشترك، والموهوم هو المؤول. وكل هذا بغض النظر عن كون اللفظ مفرداً أو مركباً، وبغض النظر أيضاً عن كونه دالا على معناه بطريق المطابقة أو الالتزام أو التضمن، وبغض النظر وسر كذلك عن كونه دالاً على المعنى بقصد أصلي أو تابع، أو بغير قصد. أما إذا فَّرَّنا عند تحديد نوع اللفظ من

$$
\begin{aligned}
& 105 \\
& 106
\end{aligned}
$$


حيث قوة دلالثه، بين المقصود وغير المقصود، وبين المدلول عليه التزاماً والمدلول عليه مطابقة، فسنعقِّد المسألة ونصِّبِ القسمة، وسندخل متاهات كثيرة لا سيما في مسألة وجود المقصود وغير المقصود في خطاب الشارع، وإذا وُجدا فكيف يكون الفصل بينهما. ومن هنا فإن ما نيل إليه هو دخول كل قطعي في مسمى النص بغض النظر عن نوع الدلالة وكوفا مقصودة أم لا. ولا يضيرنا مخالفة العرف اللغوي لأن للمعاني الاصطلاحية مقتضياتٍ خاصةُ تنفرد بها عن المعاني اللغوية.

والنص بهذا الإطلاق هو الذي ينبغي أن يُحمل عليه المراد بقولهم في القاعدة الفقهية الأصولية: "لا

اجتهاد في مورد النص،"107 أي النص بمعنى اللفظ القاطع لا النص بمعنى الخطاب الشرعي جملة؛ وذلك لأن اللفظ القاطع فقط هو الذي لا يقبل الاجتهاد في تفسيره أو تأويله بخلاف باقي الألفاظ المتملة. وعلى هذا فليس ثمة ضرورة إلى ما فعله بعض المحدثين من تقييد كلمة النص في القاعدة بالقطعية، لتصبح القاعدة قائلة

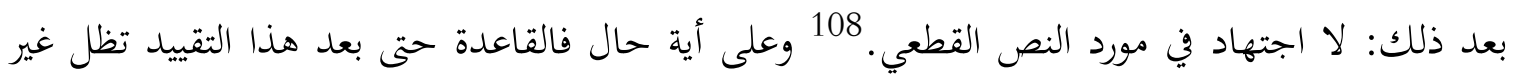
صحيحة بعمومها؛ لأن اللفظ حتى لو كان قاطعاً فإنه قابل للاجتهاد لا من حيث تفسير المراد به وإنما من حيث تطبيقه على الوقائع؛ فالنص في حدّ السرقة، مثلا، قطعي لكننا نجد أن عمر، رضي الله عنه، قد اجتهد في تطبيقه عام المجاعة فأوقف العمل به. وكذا يُقال بالنسبة للمؤلفة قلوبهم، فالنص على إعطائهم قطعي لكن عمر، رضي الله عنه، منع العطاء عنهم لأنه رأى أن إعطاءهم قد كان مقيداً بعلة حاجة الدولة لهم فلما زالت الحاجة زال الحكم. وإذا أردنا للقاعدة أن تتجاوز هذا الإشكال فلا بد من تتويرها قليلا لتصبح: "لا اجتهاد في تفسير النص"، بدلا من "لا اجتهاد في مورد النص". والله أعلم.

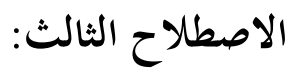
يُطلق فيه النص على "ما لا يتطرق إليه التأويل."

$$
107
$$

108 انظر، مثلا: الدريني، عمدا فتحي، المناهج الأصولية في الاجتهاد بالرأي في التشريع الإسلامي، دمشق: الشركة المتحدة للتوزيع، ط2،

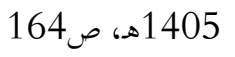


اختاره الغزالي في المنخول 109 من بين تعريفات النص. وقال إمام الحرمين: "وقد اختلفت عبارات الأصحاب في حقيقته (أي النص) فقال بعضهم: هو لفظ مفيد لا يتطرق إليه تأويل."110

وينغي أن لا نخلط في هذا المقام -كما فعل البعض_111 بين قول الأصوليين: "لا يتطرق إليه الاحتمال"، وبين قول الغزالي: "لا يتطرق إليه التأويل." وذلك لأن التأويل (الصحيح) لا يكون إلا بوجود ثلاثة أمور مجتمعة: احتمال اللفظ، ودليل التأويل، وقوة الدليل بحيث تفوق قوة الظاهر. فالاحتمال، على هذا، شرط التأويل، ووجود الشرط لا يستلزم وجود المشروط، بينما وجود المشروط يستلزم وجود الشرط، أي أن احتمالية اللفظ لا تعني وجود التأويل دوماً فقد يكون اللفظ محتملاً، ومع هذا لا يتطرق إليه التأويل لعدم توافر الشرطين الآخرين أو أحدها، بينما لا يوجد التأويل الصحيح أبداً حتى يكون اللفظ محتملاً. وعلى هذا، فالنص، بناء على هذا التعريف، يشمل نوعين من الألفاظ: أحدهما: اللفظ القاطع كألفاظ الأعداد. فهذا اللفظ غير قابل للتأويل لأنه لا احتمال فيه أصلاً. والنوع الآخر: اللفظ الظني المتمل، لكن لم يرد دليل مقبول يعضد هذا الاحتمال. فهذا النوع من الألفاظ لم يتطرق إليه التأويل أيضاً، لا لعدم احتماله للتأويل لغة، وإنما لأنه لم يرد ما يدعم هذا الاحتمال فيجعله راجحاً بعد أن كان مرجوحاً.

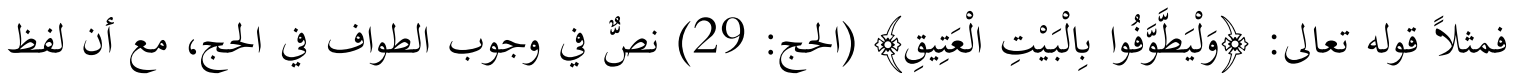

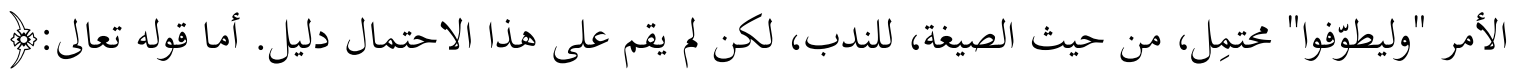

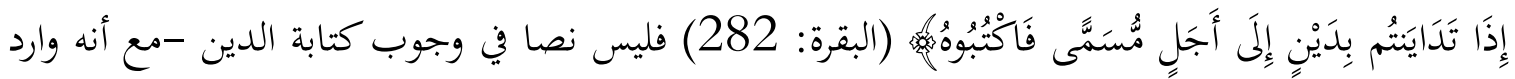

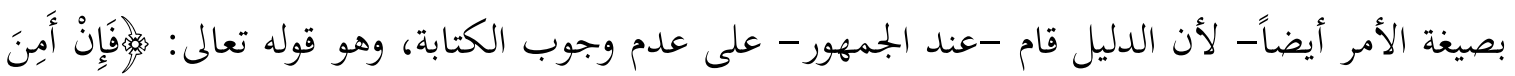

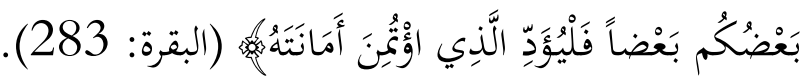

والذي يبدو لي أن الغزالي بإيراده هذا التعريف للنص لم يكن يسعى إلى "توصيف" النص في لغة الأصوليين، وإنما كان يقترح تعريفا "معدَّلاً" للنص بدلاً من التعريف "ما لا يتطرق إليه الاحتمال"؛ وذلك

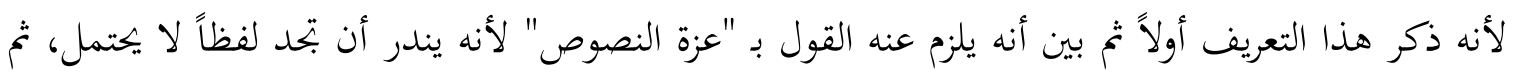

$$
\begin{aligned}
& 109 \\
& 110 \\
& 111
\end{aligned}
$$


بناء على هذا اقترح أن يُعرف النص بأنه ما لا يتطرق إليه التأويل، كي يتسنى له القول بـ "كثرة النصوص" لا

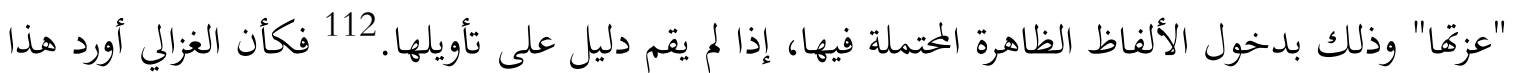
التعريف فراراً من دعوى "عزة النصوص."

وعلى الرغم من أنه يبدو أن ما قاله الغزالي في هذا السياق جديداً إلا أنه في واقع الأمر مسبوق من قبل بعض أصوليي الحنفية الذين نصوا على أن مجرد ورود الاحتمال على اللفظ لا يسلبه النصية. ولكن الفرق بين تعريف هؤلاء للنص وتعريف الغزالي له هو أفم، وبحسب الإطلاق في كلامهم، لا يقصرون مصطلح النص على اللفظ القاطع وعلى هذا النوع من الألفاظ فقط كما هو حاصل تعريف الغزالي بل يعممونه في كل واضح بحيث يشمل ثلاثة أنواع من الألفاظ القطعي والظني المتمل الذي لم يقم دليل يدعم ما احتمله، والظني المتمل الذي قام دليل يدعم ما احتمله. وإليك ما أورده الجصاص في هذا المقام، قال: "كل ما يتناول عيناً خحصوصة بحكمِ ظاهر المعنى بَيِّن المراد فهو نص." وهذا أعم من أن يكون قطعياً أو ظنياً قام الدليل على تأويله أم لم يقم. ثم قال: "وما يتناوله العموم (= المحتمل غير المؤول) فهو نص أيضاً، وذلك لأنه لا فرق بين الشخص المعين إذا أُشير إليه بعينه وبين حكمه وبين ما يتناوله العموم؛ إذ كان العموم اسماً لجميع ما تناوله وانطوى تحته. والمنصوص عليه ما نُص عليه باسمه. ومن الدليل على ذلك أن أحداً من

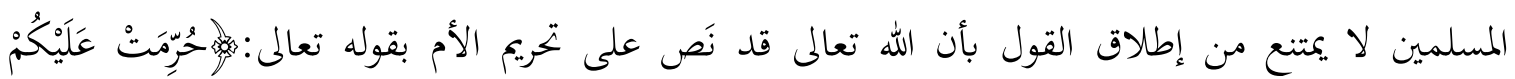

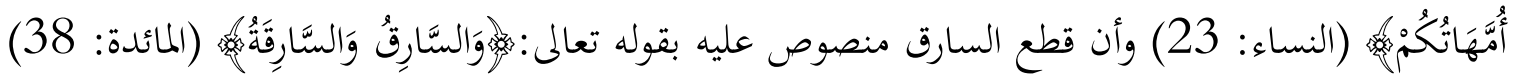
وكذلك جلد الزاني وإيجاب القصاص على قاتل العمد. وكلٌٌ إنما نُصَّ على حكمه بعموم لفظٍ ينتظم ما شمله الاسم من غير إشارة إلى عينٍ مخصوصة. وليس جواز دخول الاستثناء على لفظ العموم، وجواز تخصيصه، بمانع من أن يكون نصا إذا لم تقم دلالة التخصيص، كما أن العدد الذي يتناوله اسم العشرة منصوصٌ عليه بذكر العشرة مع جواز دخول الاستثناء عليها، ولأن المشار إليه بعينه يجوز إدخال الشرط عليه، وتعليقه بحال أخرى، ولم يمنع ذلك أن يكون نصا إذا عَري من شرطٍ أو ذكرِ حال."113 فها أنت ذا ترى أن الجصاص

112 الغزالي، أبو حامد عمد بن عمد، المنخول من تعليقات الأصول، تحقيق محمد حسن هيتو، دمشق: دار الفكر، ط2، 1400هـ، ص165 الجصاص، أبو بكر أممد بن علي الرازي، الفصول في الأصول، مرجع سابق، ص59، 60 
يدلل هاهنا على أن العين المنصوص عليها باسمها كأسماءٍ الأعلام: زيد وعمرو، وأسماءٍ الأعداد، كخمسة وعشرة، يعتريها الاحتمال كالعام، لذلك فليس من الخطأ تسوية الجميع بصحة الدخول تحت مسمّى النص. فالنص، إذن، أعم عنده من أن يكون قاطعاً أو محتملاً. 114

ومن هنا ندرك أن قول الحنفية ب " قطعية العام"، مع إقرارهم بوجود احتمال التخصيص، هو

اصطلاحٌ خاص بكم في معنى "القطع" الذي لا يَفْم منه الجمهور إلا التجرد من الاحتمال مطلقاً. 115

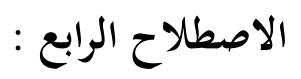

يُطلق فيه النص على: الخطاب أو اللفظ ظني الدلالة على الحكم أو المعنى. أي اللفظ الظاهر أو المحتمل لأكثر من معنى لكنه في أحدها أرجح من غيره.

قال الغزالي في المستصفى: "النص اسم مشترك يُطلق في تعارف العلماء على ثلاثة أوجه: الأول: ما

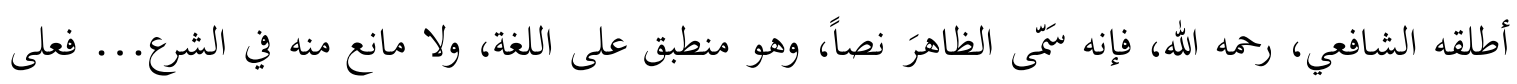

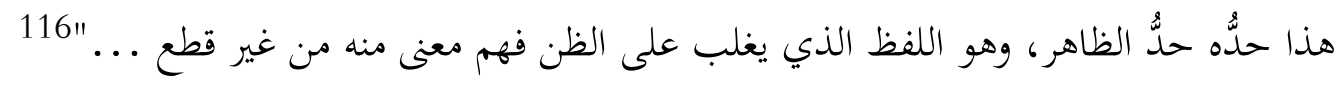
ومما يستغرب أن أحداً من الذين عددوا معاني النص في اصطلاح العلماء كالزركشي وابن دقيق العيد والقرافي وغيرهم لم يذكر هذا المعنى الذي ذكره الغزالي. ومن المستبعد جداً ألا يكونوا قد اطلعوا على كلامه في هذا الشأن. وهذا يوحي بأن ثمة خللاً ما في توصيف الغزالي للنص بأنه الظاهر بمعنى الظني. 117 وهذا ما

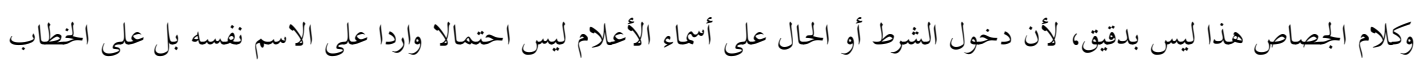
114 الموجه إلى صاحب الاسم، أمر أو هيا، والمراد إثباته هو وجود الاحتمال في الاسم نفسه. وكذلك لا تعني صحة دخول الاستثناء على أسماء الأعداد كوها محتملة لأن العدد في سياق الاستثناء (عشرة إلا ثلاثة) يصبح ذا دلالة مركبة قاطعة كحالة الجمع تماماً (عشرة وثلاثة) فأين الاحتمال؟ وإذا كان العدد يشترك مع العام في قبول الاستثناء فهو يختلف عنه في قبول التخصيص بالمخصصات المنفصلة. وشتان ما بين التخصيص بالاستثناء الذي لا يجوز أن يتراخى أو يضمر وبين التخصيص بغيره القابل لذلك عند الجماهير.

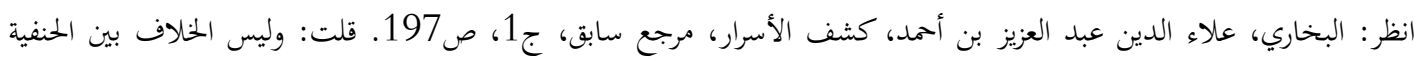
115

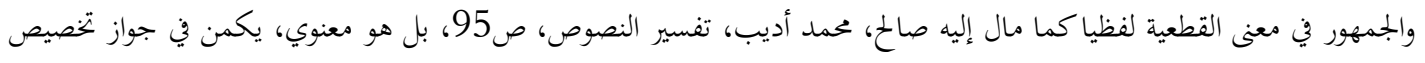

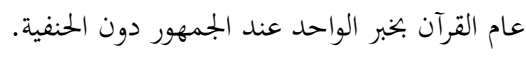

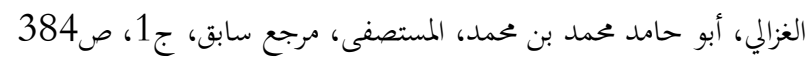
116

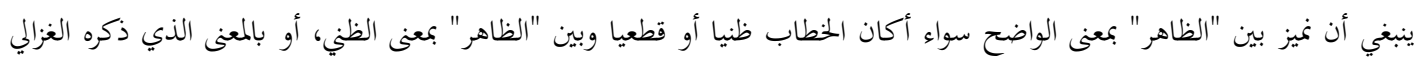
117

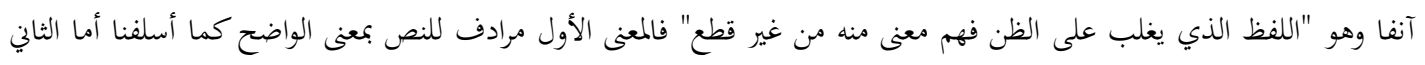


نرجحه، وذلك لأن الشافعي لما سمَّى الظاهر (= الظني) نصاً لم يكن يقصر إطلاق النص عليه، بل كان يطلقه على كل واضح سواء أكان ظنياً أم قطعياً، يدلك على هذا تعريفه للنص بأنه "كل خطاب عُلم ما أريد به من الحكم. "118 وهذا أعم من أن يكون ظنياً أو قطعياً.

وعلى هذا فنحن نشكك في وجود اصطلاح خاص بالنص يقصره على اللفظ ظني الدلالة على المعنى لا في كلام الشافعي ولا غيره. وأما بالنسبة لكلام الغزالي المنقول آنفاً فلنا رأي في تفسيره سنأتي إليه بعد

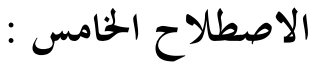

يُطلق فيه النص على "ما لا يتطرق إليه احتمالٌ مقبول يعضُده دليل، أما الاحتمال الذي لا يعضده دليل فلا يُخرجُ اللفظً عن كونه نصا، فكان شرطُ النص... (بهذا الاصطلاح)....أن لا يتطرق إليه احتمالٌ مخصوص، وهو المعتضِد بدليل." ذكره الغزالي. 119

وبناء عليه يمكننا القول بأن النص في هذا الإطلاق يكافئ أو يرادف "الظاهر المحتمِل غير المؤول"، كالعام الذي لم يقم الدليل على تخصيصه، والأمر الذي لم يقم دليلٌ على صرفه إلى غير الوجوب عند من يرى أن الأمر ظاهرٌ في الوجوب.

ولأني لم أجد أحداً يذكر هذا الاصطلاح للنص حتى من الذين جاءوا بعد الغزالي، ولأني لم أجد الغزالي يقدم دليلاً واحداً على وجود هذا الاصطلاح في لغة الأصوليين بدا لي أمران محتملان: أحدهما: أنه من الممكن أن يكون الغزالي، قد أخطأ في التوصيف هاهنا مرة أخرى كما قلته آنفاً بالنسبة للنص بمعنى الظاهر (= الظني)، حيث اغتر حينٔذٍ بإطلاق الشافعي اسم النص عليه فجعله مرادفاً له، والحق كما بينا أنه أعم منه. وكذلك نقول: اغتر الغزالي مرة أخرى بإطلاق اسم النص على اللفظ "المتمِل غير المؤول" في لغة

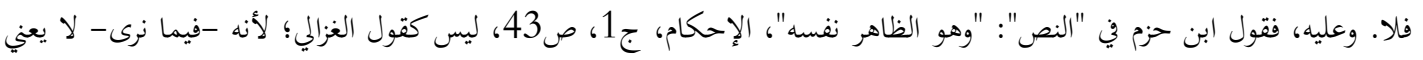

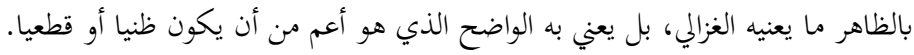

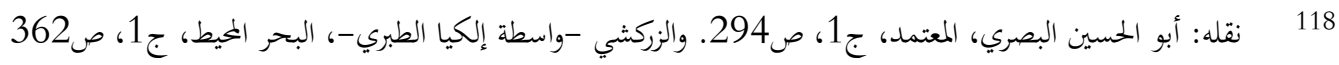
119 الغزالي، أبو حامد عمد بن المحمد، المستصفى، مرجع سابق، ص386 
بعض الأصوليين، لا سيما متقدمي الحنفية، فجعلهما مترادفين مع أن النص، عندهم، يشمل "المتمل غير

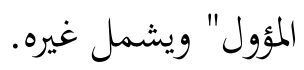

والاحتمال الثاني: وهو الذي نيل إليه، أن الغزالي لما قال: "النص اسم مشترك يُطلق في تعارف العلماء على ثلاثة أوجه"، فذكر: النص بمعنى اللفظ القاطع، والنص بمعنى الظني، والنص بمعنى المتمل غير المؤول. 120

لم يكن يقصد تعداد الاصطلاحات التي قيلت في النص، بل كان يقصد تعداد الأفراد التي تندرج تحت مسمى النص. فكأنه أراد القول: إن كلمة النص قد تطلق ويكون المراد بها اللفظ القطعي، وقد تطلق ويراد ها اللفظ الظني، وقد تطلق ويراد بها اللفظ المحتمل غير المؤول. أي أها أعم من أن تطلق على نوع واحد من هذه الأفراد. وهذا يستلزم أن يكون مراده بالاشتراك الذي وصف به مصطلح النص الاشتراك المعنوي لا الاشتراك اللفظي، أي أن النص يطلق على القدر المشترك بين هذه الأفراد الثلاثة التي تندرج تحت مسمّى النص، وهذا القدر المشترك هو الوضوح.

وتفسير كلام الغزالي على هذا النحو متعين إذا أردنا لكلامه أن يوافق الحق وما عليه محقق الأصوليين، وإلا كان كلامه دعوى من غير برهان ولا تحقيق، وهو ما نُجلُ أصولياً كبيراً كالغزالي عنه. : الاصطلاح السادس :

يُطلق فيه النص على: "ما دل على معنى قطعا، وإن احتمل غيره، كصيغ الجموع في العموم فإنها تدل على أقل الجمع قطعا وتحتمل الاستغراق" قاله القرافي. 121 ومعناه: أن النص يُطلق على اللفظ الذي يدل على أكثر من معنى، في الوقت نفسه، بحيث تكون دلالته على واحد، على الأقل، من هذه المعاني، قطعية،

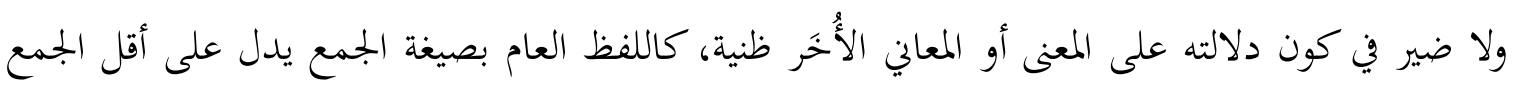

$$
120
$$

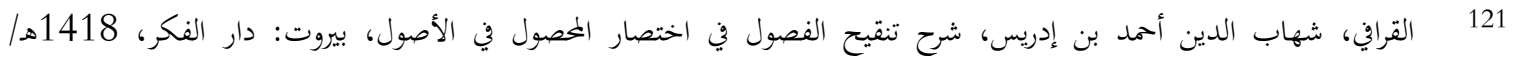

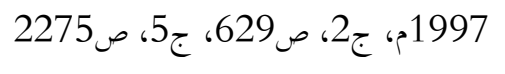


قطعا، ويدل على الاستغراق ظنا، فقول القائل: "جاء الأولاد" يدل على مجيء اثنين أو ثلاثة منهم قطعاً، ويدل، في الوقت نفسه، على بجيء الجميع ظناً.

وهذا اصطلاح مخترع، لا أظن أحدا قاله قبل القرافي.122 وقد قاله، فيما يبدو لي، استنتاجاً لا استقراء، وذلك، والله أعلم، أنه وجد بعضهم يُطلق على العام، وربما على غيره من الظواهر، مصطلح النص، فبدل أن يعتقد أن هذا الإطلاق إنما هو بمعنى الواضح الأعم من أن يكون قطعياً أو ظنياً، ظن أن ذلك ناتج عن كون العام بصيغة الجمع قاطعاً في جزء من دلالته، وهي التي تكافئ أقل الجمع، ظنياً في الباقي. ويؤيد رأينا هذا عدمُ ذكره -أي القرافي- لاصطلاح النص بمعنى الواضح (= القطعي + الظني) من بين الاصطلاحات الثلاثة التي ذكرها في النص مما يؤكد كونه غفل عن كون النص يُطلق بهذا الاصطلاح، ولذا استعاض عنه باستنتاجه لاصطلاحه المذكور.

واستتناجه هذا ليس صواباً فيما نرى؛ لأنا قد بينا في التمهيد لهذا المطلب أنْ لا خطاب أصلاً إلا وتعتريه الدلالتان القطعية والظنية بالنسبة للمعاني المختلفة في الوقت نفسه، وحيئذٍ، وبناء على تعريف القرافي، يجوز وصف كل خطاب بأنه نص، وبالتالي ينعدم الفرق بين النص بمعنى الخطاب الشرعي مجرداً، أو بتعبير القرافي "ما دل على معنى كيف كان"، 123 وبين النص بهذا الاصطلاح الجديد، لأن النص في كلا الإطلاقين سيدل على معنى ما قطعاً وعلى آخر ظناً، وقد جعلهما القرافي اصطلاحين مختلفين لا واحداً!

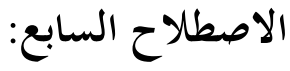

يُطلق فيه النص على: "ما ازداد وضوحاً على الظاهر بمعنى من المتكلم لا في نفس الصيغة." "والظاهر

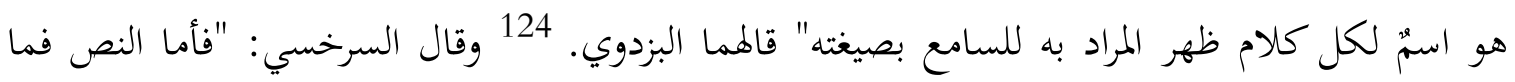

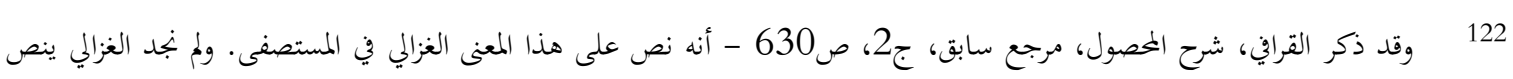

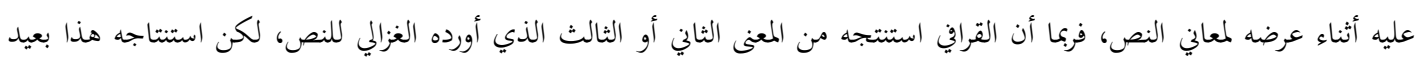
للغاية، وليس ثمة ما يشير إليه. 123

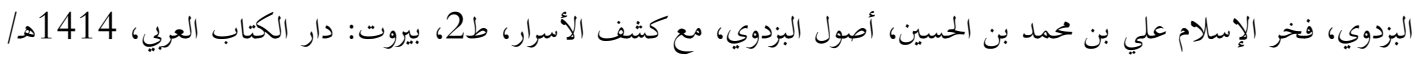


يزداد بيانا بقرينة تقترن باللفظ من المتكلم ليس في اللفظ ما يوجب ذلك ظاهراً بدون تلك القرينة."125 وقال: صدر الإسلام أبو اليسر: "النص فوق الظاهر في البيان لدليلٍ في عين الكلام." "126 وقال اللامشي:

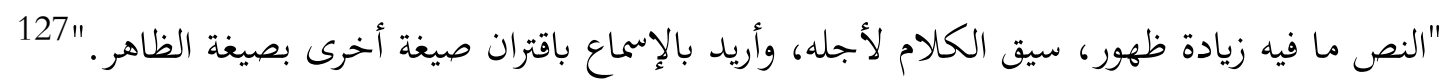
ولعلك أدركت من خلال الأسماء التي نقلنا عنها هذه التعريفات أن هذا الاصطلاح خاصٌ بالحنفية، بل بالمتأخرين منهم فحسب، إذ قد وجدنا الجصاص (ت 370هـ) مثلاً، يُعرِفِ النص تعريفاً مغايراً لما استقر عليه المتأخرون يكاد يتفق مع الجمهور في كونه بمعنى الواضح الأعم من أن يكون سيق له الكلام أو لا. وعلى هذا الاصطلاح يتميز النص عند متأخري الحنفية، بكونه: واضح المعنى، قطعي الدلالة (بالمعنى الحنفي)، محتمِل، سيق له الكلام.

هذا، وعلى الرغم من أهمية ما ينبّه إليه هذا الاصطلاح من حيث هو يجعل للسياق دوراً واضحاً في دلالة الخطاب، إلا أنه اصطلاح غير مستخدم في اللغة الأصولية حتى عند الحنفية الذين ذكروا هذا الاصطلاح أنفسهم؛ فباستقراء سريع عن طريق الحاسب الآلي لاستخدام السرخسي في أصوله لمصطلح النص وجدت أنه لا يستخدمه بهذا الإطلاق الذي عرفه به إلا عند الحديث عن درجات الوضوح والخفاء في النصوص، أما في باقي المواضع فيشيع استخدامه إياه بمعنى الخطاب بجرداً أو بمعنى الخطاب الواضح، أو بمعنى الخطاب القاطع، دون التفات للسياق كما يقتضي التعريف. وعليه، نرى أن هذا الاصطلاح للنص هو اصطلاح "مقترح" أو "معدَّل" لا "توصيفي." ولست أحبذ الدعوة إليه لأنا، فضلاً عن عدم حاجتنا لمثل هذا الاصطلاح، نطمح في اللغة العلمية إلى الابتعاد، قدر الإمكان، عن الألفاظ والاصطلاحات المشتركة، والحد من وجودها لا العكس.

$$
126 \text { 125 } 125
$$

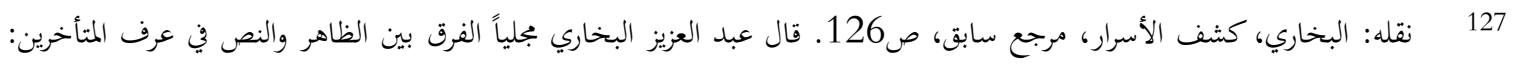

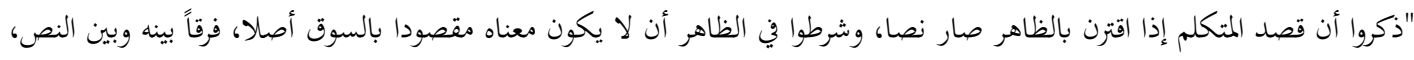

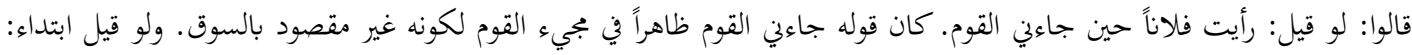

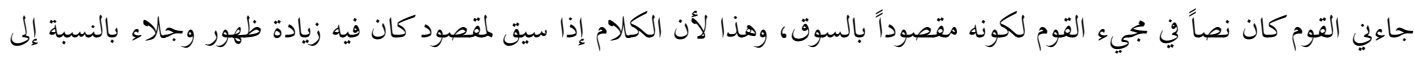

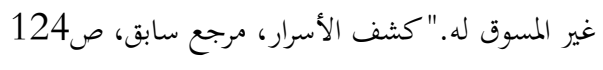




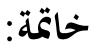

يتلخص لدينا بعد إيراد ما سبق كله أن استخدام الأصوليين لمصطلح النص مجرداً إنما هو في معاني

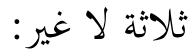

$$
\text { الأول: النص بمعنى الخطاب الشرعي كتاباً أو سنة بغض النظر عن دلالته. }
$$

والثاني: النص بمعنى الخطاب ذي الدلالة الواضحة، سواء أكانت دلالته قطعية أو ظنية.

$$
\text { والثالث: النص بمعنى الخطاب ذي الدلالة القاطعة. }
$$

وهي الاصطلاحات التي اقتصر على ذكرها العلامة المحقق ابن دقيق العيد رحمه الله تعالى.128

أما باقي الاصطلاحات التي ذكرها الأصوليون فقد بينا أها اصطلاحات إما لا استعمال أو واقع لما: كالنص بمعنى "الظني" فقط، والنص بمعنى "المتمل غير المؤول" فقط كما هو ظاهر كلام الغزالي، والنص بمعنى "اللفظ الذي يُشترط شموله، في نفس الوقت، على نوعي الدلالة القاطعة والظنية" كما قاله القرافي، وإما أغها معدلة (= مقترحة) ولم يتهيأ لها الذيوع والانتشار، كالنص بمعنى "ما لا يتطرق إليه التأويل"،كما اقترحه الغزالي، والنص بمعنى "الواضح الذي سيق له الكلام" كما قاله متأخرو الحنفية.

كما قد تكون هذه الاصطلاحات نادرة جداً في اللغة الأصولية كالنص بمعنى "كلام الإمام الشافعي"، وإما تُشترط لها الإضافة كالنص بمعنى "قول القائل بحروفه."

$$
\text { وهذه النتيجة تقودنا إلى تقديم عدد من الاقتراحات وهي: }
$$

1. حسم الاستعمال الأصولي المعاصر فيما يتعلق بالخطاب أو النص لصالح أحدها، وليكن النص. أما الخطاب فلا أرى إلغاءه وإنما جعله عاماً ليضم خطاب الشارع وغيره. وعليه، فالخطاب، مجرداً، يتناول كل كلام بغض النظر عن قائله، أما النص، مجرداً، فلا يُطلق إلا على خطاب الشارع فقط.

$$
128 \text { ن نقلها عن كتابه"شرح العنوان، السبكي، علي بن عبد الكافي، الإجماج في شرح المنهاج، ج1، ص215 }
$$


2. اقترح وضع حد دقيق للنص بمعنى الخطاب، وذلك لأن الحدود التي ذكرها الأصوليون للنص بهذا

الإطلاق هي مجرد تعريفات لفظية أو توصيفات. وعلى الحد الموضوع أن يجيب عن مجموعة من الأسئلة التي ترد على حد النص منها:

$$
\text { هل يشمل النص الفعل والتقرير النبوي أم لا؟ }
$$

هل يُشترط فيما روي عن الشارع أن يكون ثابتاً حتى يوصف بأنه نص؟ أم نصف كل ما نسب إلى

الشارع بأنه نص حتى لو روي بسند ضعيف مثلاً؟

هل هنالك حدود ضابطة للنص، أعني بداية وهاية؟ فهل يطلق النص على اللفظ المفرد مثلاً أم لا بد

من التركيب؟ وإذا اشترطنا التركيب فإلى أي مدى؟ فهل نقول بأن النص هو الجملة المفيدة عن الشارع؟ أم هو تتابع مطلق من الجمل؟ أم هو مجموعة من الجمل تتعلق بموضوع واحد؟ أم هو بجموعة من الجمل وردت عن الشارع في زمن واحد؟129 من من من

وفي هذا الصدد أرى تعريف النص بكونه: "اللفظ المركب المفيد لفائدة تامة الوارد في الكتاب أو السنة الثابتة." أو قل: "هو الجملة المفيدة الواردة في الكتاب أو السنة الثابتة." وبهذا التعريف نكون قد اشترطنا في النص كونه جملة مفيدة يحسن السكوت عليها، وكذا اشترطنا ثبوته عن الشارع، وكذا أدخلنا الفعل والتقرير النبويين ضمن الحد.

وفي هذا المجال يمكننا أن نستفيد من علوم اللغة المعاصرة لا سيما ما يسمى بعلم لغة النص. وقد اختلف علماء لغة النص في المعيار

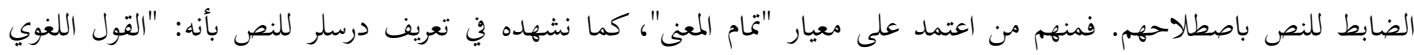

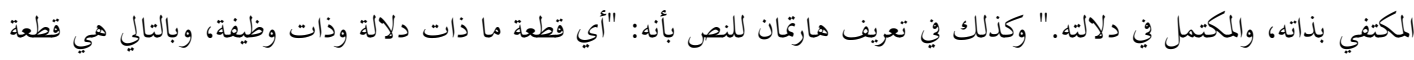

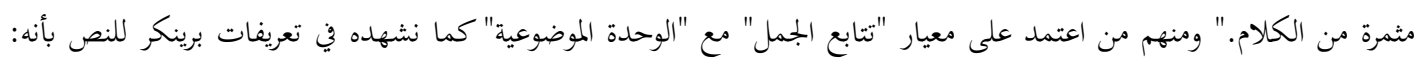

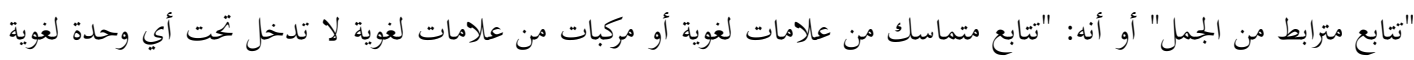

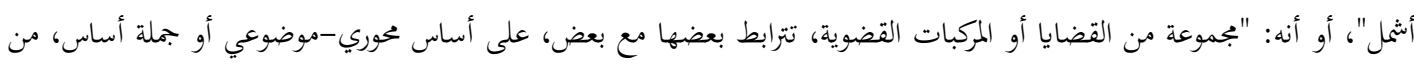

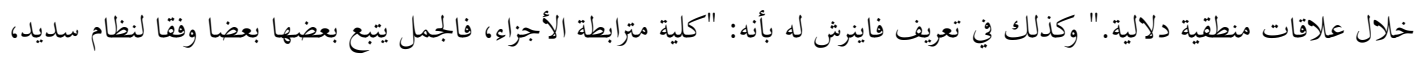

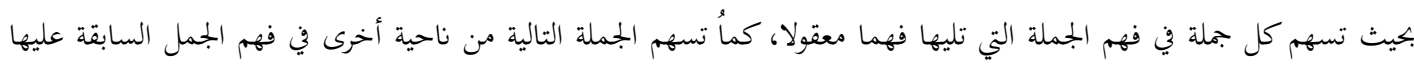

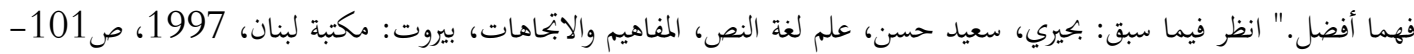


3. الاستغناء عن هذا المعنى الاصطلاحي للنص، وذلك تجنباً للاشتراك اللفظي بينه وبين النص بمعنى اللفظ القطعي. فإذا قيل: إن هذا المعنى الاصطلاحي للنص كان قد ضَمُر أو تلاشى عند المتأخرين من الأصوليين، وهو لا يوجد إلا عند المتقدمين. وعليه فاقتراحك الاستغناء عنه هو تحصيل حاصل. فأقول: هذا صحيح، ولكني باقتراحي هذا أهدف إلى أن لا يأتي أحدهم في الوقت الراهن فيعمد إلى إحياء هذا الاصطلاح من جديد.

4. انطلاقاً من القول بنسبية القطعية والظنية في دلالة النص الشرعي ونفياً للاشتراك بين هذا الاصطلاح والاصطلاح الأول، فإني اقترح أن لا يُستعمل النص بهذا الإطلاق مجرداً وإنما مضافاً إلى المعنى

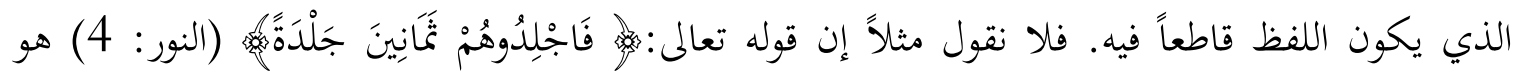
نص، بل نقول هو نص في عدد الجلدات. وبناء عليه يكون مصطلح النص ألصق بالمعنى منه باللفظ، فنقول في تعريف النص بهذا الإطلاق هو المعنى الذي يدل عليه اللفظ دلالة قطعية تماماً كما نقول في تعريف ظاهر اللفظ بأنه المعنى الذي يدل عليه اللفظ دلالة ظنية.

وأخيراً نأمل بهذه الدراسة أن نكون قد ولَّدنا شيئاً من الحافز لمم الباحثين في سبيل معالجة مشكلة الاصطلاح في تراثنا الأصولي. 